\title{
Personal Bankruptcy: Reconciling Adverse Events and Strategic Filing Hypotheses Using Heterogeneity in Filing Types
}

\author{
By \\ Li Gan, Tarun Sabarwal, and Shuoxun Zhang ${ }^{1}$
}

This version: October 17, 2012

\begin{abstract}
Personal bankruptcies have continued to rise even after passage of a comprehensive reform designed to curb strategic use of bankruptcy. We formalize a distinction between strategic filing and adverse events filing by testing whether consumers manipulate their debt and filing decision or not. Test results are consistent with adverse events hypothesis and are replicated using PSID and SCF data. Extending the analysis to allow for both types, there is evidence of heterogeneity in filing types, consistent with both hypotheses. On average, approximately 16 percent of households are more likely to behave as strategic types and 84 percent as adverse events types.
\end{abstract}

Keywords: Consumer bankruptcy, personal bankruptcy, adverse events, strategic filing JEL Classification: K35, D12, D14

\footnotetext{
${ }^{1}$ Gan: Department of Economics, Texas A\&M University, and NBER, gan@econmail.tamu.edu Sabarwal: Department of Economics, University of Kansas, sabarwal@ku.edu

Zhang: Research Institute of Economics and Management, Southwestern University of Finance and Economics, Chengdu, China, shuoxun@swufe.edu.cn.
} 


\section{Introduction}

Personal bankruptcy rates have increased at an annual rate of 3.9 percent since 1990, from about 718 thousand (non-business) bankruptcies in 1990 to about 1.5 million in 2010 . There has been widespread debate about the causes of this increase and policy responses to this phenomenon.

Partly as a response to this increase, the Congress passed the Bankruptcy Abuse Prevention and Consumer Protection Act of 2005, the largest overhaul of bankruptcy laws since 1980. The new law was aimed to reduce strategic use of bankruptcy filing, even though it is not known whether strategic use of bankruptcy is widespread or increasing. Indeed, other than a spike in bankruptcy filings in 2005 (just before the law took effect in 2006) and a corresponding decline in 2006, bankruptcies have continued to rise, reaching a level of about 1.5 million in 2010, the same level as in 2004.

Understanding the motivations of consumers to file for bankruptcy is central to the design of appropriate policies to manage the number of filings. If consumers typically file strategically, and it is determined that filings are too high, then policies to reduce filings could include, among others, those that tighten access to bankruptcy courts, or make bankruptcy more expensive, perhaps by restricting access to particular types of bankruptcy provisions, lowering exemptions, diverting more debtors to longer repayment plans, lengthening minimum time between repeat filings, or requiring debt management programs outside of bankruptcy. On the other hand, if consumers typically file due to adverse events, then policies to reduce bankruptcy filings could include, among others, those that minimize the impact of adverse events, or increase financial literacy for planning for such events.

We formalize a distinction between a strategic filing and an adverse events filing by testing whether consumers manipulate their debt and filing decision or not: that is, whether financial benefit is endogenous to the filing decision or not. Intuitively, adverse events filers use bankruptcy mainly due to adverse events such as job loss, medical problems, or divorce; their debt (and consequently, financial benefit from a bankruptcy filing) is typically exogenous to the filing decision. Strategic filers may additionally manipulate unsecured debt before a bankruptcy filing; their financial benefit is endogenous to the filing decision. 
Using two different datasets (PSID and SCF), the test results are consistent with the adverse events hypothesis. Extending the analysis to allow for both types, there is evidence of heterogeneity in filing types, consistent with both hypotheses. Our estimates show that approximately 16 percent of households are more likely to behave as strategic types and 84 percent as adverse events types.

Although both datasets are among the best publicly available datasets of their kind, they have well-known limitations for bankruptcy research. Using two datasets provides some robustness checks, but better bankruptcy data would help to arrive at stronger conclusions.

Our analysis helps understand and reconcile the adverse events and the strategic filing hypotheses.

The adverse events hypothesis postulates that consumers file for bankruptcy mainly because they experience adverse events, and financial stresses associated with such events. ${ }^{3}$ Adverse events occur, for example, in the form of a job loss, medical problems, and particular family issues such as divorce. Financial stresses associated with such events arise, for example, in the form of income interruption, income reduction, or debt increase.

The strategic filing hypothesis postulates that a rational consumer incorporates in her decisionmaking, the bankruptcy option available under law, and its associated costs and benefits, makes the best use of her economic environment, and chooses an optimal time to file for bankruptcy. In particular, if the best choice includes a strategic, and lawful, use of debt and the bankruptcy system, then that is reflected in consumer choice.

At the heart of each hypothesis is the role of financial benefit in the bankruptcy filing decision.

\footnotetext{
${ }^{3}$ The literature on consumer bankruptcy is very large. A partial list includes the following. Girth (1971) presents early work in this area. Sullivan, Warren, and Westbrook $(1989,1994$, and 2000) present a version of the adverse events theory. White (1987, 1998), Domowitz and Sartain (1999), Gross and Souleles (2002), Fay, Hurst, and White (2002), Fan and White (2003), Han and Li (2004), Livshits, Macgee, and Tertilt (2007, 2008) explore versions of adverse events and strategic filing theories and their impact on micro and macro decisions. Ausubel $(1991,1997)$ explores aspects of competition in the credit card industry. Theoretical models for default and bankruptcy with competitive and incomplete markets are considered in Zame (1993), Modica, Rustichini, and Tallon (1999), Araujo and Pascoa (2002), Sabarwal (2003), Dubey, Geanakoplos, and Shubik (2005), Geanakoplos and Zame (2007), and Hoelle (2009), among others.
} 
In the "strict" interpretation, strategic filing hypothesis holds, if, ceteris paribus, filing benefit affects the bankruptcy decision positively, and adverse events hypothesis holds, if, ceteris paribus, adverse events variables affect a consumer's decision to file. Using data from the Panel Study of Income Dynamics (PSID), Fay, Hurst, and White (2002), (henceforth, FHW, show that financial benefit is positively and significantly related to the filing decision, and after controlling for financial benefit, adverse events variables do not affect the bankruptcy decision (except for a marginally significant positive effect of divorce). Using Survey of Consumer Finances (SCF) data, we document a similar effect of financial benefit, but a strongly significant and positive effect of divorce. Thus, using the strict interpretation, the PSID dataset provides some support for the strategic hypothesis while the SCF dataset provides some support for both the strategic and the adverse events hypothesis.

The strict interpretation implicitly assumes that strategic behavior is the only behavior affecting financial benefit.

More realistically, financial benefit from filing goes up when a consumer strategically increases unsecured debt before filing, consistent with strategic behavior; and it also goes up when she uses unsecured debt (e.g. a credit card) to pay for expenses due to adverse events, consistent with adverse events behavior. Therefore, financial benefit is affected by both types of behavior, and a positive coefficient on financial benefit alone may not be sufficient to distinguish between the two hypotheses. This point may be made more generally; we show that in the standard random utility model underlying the binary choice of filing and not filing, the coefficient on unsecured debt (and hence, on financial benefit from filing) is positive, regardless of how debt is accumulated.

In this paper, we propose that even when financial benefit may affect the filing decision in either hypothesis, the inclusion of financial benefit as an optimizing variable is a testable difference between the two hypotheses. In other words, strategic consumers may additionally manipulate debt before filing, but adverse events consumers do not. We formalize this distinction by inquiring whether financial benefit is exogenous or endogenous to the filing decision. ${ }^{4}$ The

\footnotetext{
${ }^{4}$ FHW do not explore potential endogeneity of financial benefit.
} 
discussions provide a set of natural instrumental variables, the adverse events. Using both PSID data and SCF data, we show that financial benefit is exogenous to the bankruptcy decision, consistent with adverse events hypothesis. With both datasets, the coefficient on financial benefit from filing is strongly significantly positive.

To inquire into the possibility of both types of behavior existing simultaneously, we extend the analysis by estimating a model with two unobserved types. We find evidence of heterogeneity in types consistent with both behavior. In particular, financial benefit is shown to be endogenous for the strategic type, and exogenous for the adverse events type. The coefficient on financial benefit is significantly positive for the strategic type and positive but insignificant for the adverse events type. These results show a role for both hypotheses.

Moreover, most of the variables for adverse events have the same effect on financial benefit for both types, but with a larger absolute effect for strategic types. Not working lowers financial benefit, increasing unemployment spell increases financial benefit, and divorce increases financial benefit. Health problems present a mixed picture, a positive (and marginally significant) effect on financial benefit for adverse types, but decreasing (and insignificant) effect for strategic types. These results document a financial-benefits channel for adverse events.

As the types are unobserved, a mixture-density type of model is used. The exclusion restriction includes access to debt markets (in terms of the number of credit cards), income, a measure of risk aversion, and a measure of financial savviness. Henry, Kitamura, and Salanie (2010) provide conditions for the non-parametric identification of mixture-density models. Both Henry, Kitamura and Salanie (2010) and Gan, Huang, and Mayer (2011) suggest a Hausman-type specification test. We find supporting evidence of the current two-type model when applying the test.

We find that lower access to debt markets and lower income significantly increase the chance of strategic behavior. There is little evidence, however, of the effect of risk aversion and financial savviness.

For comparisons between the two types, the population is divided into two groups. A household is of strategic type, if its type probability is greater than 0.5 , and is of adverse events type 
otherwise. On average, about 16 percent of the sample is strategic type, and 84 percent is adverse events type, providing support for the exogeneity of financial benefit in the one-type model. We find that as compared to adverse events types, strategic types have higher probability of filing and higher (log) financial benefit from filing given everything else equal, consistent with the theoretical framework.

The estimated model is used to predict effects of hypothesized changes in key variables. In particular, we document the effects on filing probabilities resulting from the effect of adverse events on financial benefits; exhibiting a financial-benefits channel for adverse events effects.

As bankruptcy is a form of insurance, the ideas here may be related to moral hazard in insurance markets, as follows. Moral hazard relates to increasing the benefit from insurance by taking some (additional) actions that increase insurance payoffs. In our version, strategic filing behavior is similar to moral hazard, in the sense that these consumers may additionally increase unsecured debt before filing to increase their financial benefit from filing. Adverse events consumers do not exhibit such moral hazard. Thus, another way to formulate a distinction between the two hypotheses is to inquire whether, and to what extent, moral hazard is present in the bankruptcy decision. $^{5}$

The paper proceeds as follows. Section 2 presents the theoretical models and testable predictions, and section 3 presents the econometric specifications, data, and results.

\section{Theoretical Models and Predictions}

First, we show a positive relationship between unsecured debt and probability of filing for bankruptcy, regardless of how debt is accumulated. Next, we formulate simple models of adverse events and strategic filing hypotheses, and highlight their different predictions.

\subsection{A Positive Correlation between Financial Benefit and Filing Probability}

\footnotetext{
${ }^{5}$ The question of adverse selection is not as relevant here; in principle, everyone under the U.S. legal jurisdiction has access to bankruptcy, without having to pay something to be selected into having a bankruptcy option.
} 
FHW indicate that a positive and significant relationship between household financial benefit and probability of filing for bankruptcy signals strategic behavior by a consumer. Similarly, Adams, Einav, and Levin (2009) suggest that an increase in probability of default with loan size is consistent with either moral hazard behavior or adverse selection behavior. In the same spirit, we present a simple model showing that financial benefit may affect the probability of filing, regardless of how debt is accumulated.

In most empirical work, filing for bankruptcy is modeled as a binary choice model. According to McFadden's Random Utility Maximization model, a person would file for bankruptcy if his utility difference between filing and not filing is positive. To investigate this difference, let $d$ be unsecured debt and $w$ be assets minus secured debt. For simplicity, the exemptions are normalized to be zero. Financial benefit from filing, given $d$, is $f b(f i l e, d)=\max (d-w, 0)$, and financial benefit from not filing, given $d$, is $f b(N o t, d)=\max (w-d, 0)$. Notice that $f b(f i l e, d) \geq f b($ Not, $d)$ if and only if $d \geq w$.

Let $u$ denote utility from monetary outcomes. Assume that $u$ is strictly increasing and continuously differentiable. We may write utility from filing, given $d$ as: $U($ file, $d)=u(f b(f i l e, d))$; utility from not filing, given $d$ as $U($ Not,$d)=u(f b($ Not,$d))$; and the difference in these utilities is $\Delta U(d)=U($ file, $d)-U($ Not,$d)$. Therefore,

$$
\Delta U^{\prime}(d)=u^{\prime}(f b(\text { file, } d)) f b^{\prime}(f i l e, d)-u^{\prime}(f b(\text { Not }, d)) f b^{\prime}(\text { Not }, d) .
$$

Consider the following cases.

$d>w$ : In this case, $f b^{\prime}($ file, $d)=1$ and $f b^{\prime}($ Not,$d)=0$. Therefore, $\Delta U^{\prime}(d)=u^{\prime}(f b($ Not,$d))>0$.

$d<w$ : In this case, $f b^{\prime}($ file, $d)=0$ and $f b^{\prime}($ Not,$d)=-1$, whence, $\Delta U^{\prime}(d)=u^{\prime}(f b($ Not,$d))>0$.

$d=w$ : In this case, $\lim _{d \downarrow w} u^{\prime}(f b(f i l e, d))=u^{\prime}(f b($ file, $w))=u^{\prime}(0)>0$, and similarly,

$\lim _{d \uparrow^{\prime} w} u^{\prime}(f b(N o t, d))=u^{\prime}(f b($ Not,$w))=u^{\prime}(0)>0$.

In all cases, we have $\Delta U^{\prime}(d)>0$. 
In terms of empirical prediction, this implies that the coefficient on unsecured debt (and consequently, on financial benefit from filing) is positive, regardless of how debt is accumulated. ${ }^{6}$ Therefore, given unsecured debt $d$, a positive relationship between financial benefit from filing and filing for bankruptcy is expected.

\subsection{Adverse Events Hypothesis}

Frequent support for adverse events hypothesis has been advanced by Sullivan, Warren, and Westbrook (1989, 1994, 2000), among others. Using data from bankruptcy filings in 1981 (for Illinois, Pennsylvania, and Texas), and in 1991 (for Illinois, Pennsylvania, Texas, California, and Tennessee), these authors paint a rich portrait of consumers in bankruptcy, they present statistics that indicate similarities between bankrupt debtors and the general population, especially middle-class families, and they present a variety of cases and statistics to conclude that while some cases of abuse of bankruptcy law may exist, bankruptcy is predominantly due to adverse events. As they put it succinctly, "No one plans to go bankrupt."

In terms of formulating a model for this hypothesis, it is useful to keep in mind that a pattern that emerges consistently in this hypothesis is that there are some events for which consumers do not plan (even if they may, in principle, be aware of the existence of such events), and if such an event occurs, then they may be compelled to file for bankruptcy. If such an event does not occur, consumers do not consider filing for bankruptcy. For a statement like this to be true in a model of this hypothesis, it is important to answer at least two questions. First, why don't consumers plan for some events? Second, even if they don't plan for some events, why do they not include a bankruptcy option in the events for which they do plan?

Consumers might not plan for some events if they assign an event a subjective probability of zero. For example, we observe that in surveys of individual mortality, some consumers list as zero their probability of next-period mortality (Gan, Hurd, and McFadden, 2005). Such an assignment can arise if the cost of making very fine probability distinctions is relatively high, or

\footnotetext{
${ }^{6}$ Notice that all we used here was that $u$ is strictly increasing and continuously differentiable. No additional restriction is imposed on utility.

${ }^{7}$ Sullivan, Warren, and Westbrook (2000), page 73 .
} 
it can arise as a mistake that has a miniscule impact. For example, in the PSID data, the probability of bankruptcy is 0.003017 , as reported in FHW.

It is somewhat harder to justify theoretically why, in events for which consumers otherwise plan, they do not include a bankruptcy option that is legally, and in principle, widely available. One explanation for this is that ex ante, the benefit from a bankruptcy filing is low relative to costs; for example, as reported in FHW, for families that can gain from a bankruptcy filing, the mean benefit from filing is $\$ 7,813$, and the probability of filing is 0.003017 , for an ex-ante filing benefit of about $\$ 25$. This is less than the cost of a planning session with a bankruptcy lawyer, or the resources expended to purchase and plan with a book on how-to-file. Another explanation can be provided in terms of utility penalties arising from future reputation losses from filing; for example, see Dubey, Geanakoplos, and Shubik (2005). Such losses can arise from a combination of restricted future access to debt markets, credit score impact (for severity of credit score impact, see Musto 2004,) and loss of option to re-file for some period (six years for a Chapter 7 filing). If such losses are very high when consumers file in the absence of adverse events, and such losses outweigh benefits of filing, then in non-adverse events, consumers may optimally decide not to consider a bankruptcy option. For example, a bankruptcy flag on a consumer credit report is one of the worst derogatories on a credit report, and it stays there for ten years, but the legal system allows a Chapter 7 re-filing after six years. Consequently, the longer memory of financial institutions of a consumer bankruptcy filing increases the cost of filing by increasing future costs of accessing debt markets.

Therefore, as a first approximation, we may view adverse events consumers as taking decisions sequentially; in period 1, they plan for some events, and in such events, they do not plan to file for bankruptcy, but they do not plan for other events (termed adverse events). In period 2, if a planned-for event occurs, they consume as planned, and if an adverse event occurs, they include a bankruptcy option in their decision-making and re-optimize accordingly. In other words, in period 1, "adverse events consumers do not plan to go bankrupt." A simple two-period decisionmaking model formalizing this is given in the appendix.

\subsection{Strategic Filing Hypothesis}


A strategic filing consumer is a standard fully rational consumer who includes the bankruptcy option in her maximization problem. A comparable two-period decision-making model is presented in the appendix.

\subsection{Comparisons between the Hypotheses and Empirical Predictions}

One distinction between strategic filing and adverse events hypothesis is that for strategic filing consumers, the bankruptcy decision and the debt decision (and consequently, financial benefit) are jointly determined, whereas for adverse events consumers, the debt decision (and consequently, financial benefit) is exogenous to the filing decision. This follows immediately from the discussion above, and can also be seen in the formalized model in the appendix.

Moreover, a strategic consumer files whenever it is in her financial interest; that is, whenever unsecured debt is high; whether due to adverse events or due to a strategic increase in debt before filing. This yields another prediction: a strategic consumer has a higher probability of filing (intuitively, files at a higher rate, or more frequently) that an adverse events consumer. This can be seen in the formalized model in the appendix.

Furthermore, a strategic consumer's use of debt is sometimes more but never less than debt use by an adverse event's consumer. When debt limits are sufficiently low, both types might decide to use maximum possible debt, and in this case, debt levels are the same. But the optimal debt level for adverse events consumers can be lower than that for strategic consumers, because adverse events consumers plan to remain solvent in states for which they plan. This can be seen in the formalized model in the appendix.

In summary, the empirical predictions from the theoretical analysis include: (a) financial benefit is endogenous to the bankruptcy decision in the strategic filing hypothesis and exogenous in the adverse events hypothesis; and (b) financial benefit and probability of filing for bankruptcy are higher in strategic filing hypothesis than in adverse events hypothesis.

\subsection{Some Limitations}

The models presented above are simple models, and by no means capture all relevant aspects of the bankruptcy decision. Issues related to choosing a particular period to file for bankruptcy, or 
to repeat interactions with credit markets, or to choice of bankruptcy chapter, or to role of legal advertising, or to effects on supply of credit, or to effects on work incentives, and so on are not considered here. (Some of these are the subject of other papers, listed above.) It is possible to consider some of these issues here in a reduced form by including parameters for expected gains and losses from delaying a decision, or reduced access to credit markets, or utility penalties for default, and then focusing on parameter values which make particular versions of the models more likely to occur, but it is unclear if such additions would yield tractable models, or have additional applications given the paucity of available data.

The results here can be viewed as providing an indication of alternative hypotheses being borne out in the data, rather than a definitive conclusion in favor of one hypothesis or the other. For example, in addition to research supporting different hypotheses, the reported surge in bankruptcy filings before the deadline of October 17, 2005 for the new bankruptcy law to go into effect suggests that other factors (perhaps informational spillovers emerging from declining social stigma, or lawyer advertising) are important as well. No doubt, additional work may yield additional testable predictions, and additional research would be very welcome.

\section{Econometric Models and Results}

In this section, we first provide some information on the data and construction of variables. Next, we present three specifications and estimation results for each specification. The specifications considered are: a simple Probit model, a one-type model (with joint maximum likelihood estimation), and a two-type model (with joint maximum likelihood estimation).

\subsection{Data description and variables}

We use two different datasets to check robustness of our results. One is the combined crosssection and time series sample of PSID households over the period 1984-1995; the same dataset is used in FHW. The other is the cross sectional dataset of SCF from $1998^{11}$.

\footnotetext{
${ }^{11} \mathrm{SCF}$ asks the respondents about their bankruptcy history, but this variable is not revealed to the public after 1998. So we choose the data of the most recent year.
} 
In 1996, the PSID asked respondents whether they had ever filed for bankruptcy and if so, in which year. This information, combined with other household characteristics forms the basis of our first dataset. The PSID data are generally of high quality, but they have some limitations for a study of this kind. In particular, wealth is only measured at 5 -year intervals, and it contains less detail on some aspects of use in this study. Moreover, as documented in FHW, there are only 254 bankruptcy filings over the period 1984-1995, and bankruptcy filings in the PSID are only about one-half of the national filing rate.

SCF, in contrast, has 55 bankruptcy filings in 1997, or about 1.28 percent of households, comparable to the 1997 national bankruptcy filing rate of 1.16 percent. The SCF is crosssectional only, so we lose the time-series aspect in this case; but there is some information for the year prior to the survey, and on future expectations.

SCF also provides us with better wealth data, which reports 1997 wealth information and 1997 bankruptcy filings. (The survey itself was conducted between June and December of $1998 .{ }^{12}$ ) In table 1, we compare financial benefits (discussed below) and unsecured debt between filers and non-filers for both PSID and SCF. Similar patterns emerge. In PSID, the mean $\log$ (financial benefit) for filers is more than twice as much than those non-filers. In SCF, filers have more than three times as much mean $\log$ (financial benefits) than non-filers. In both SCF and PSID, the mean $\log$ (unsecured debt) for filers is greater than that of non-filers.

Financial benefit from filing is the key variable in this paper. It is calculated as follows:

$$
f b=\max [\text { debt }-\max (\text { wealth }- \text { exemption }, 0), 0]
$$

In this formula, $\max ($ wealth-exemption, 0 ) calculates the nonexempt assets that a filer loses in bankruptcy. It measures financial cost of filing for bankruptcy. ${ }^{13}$ The variable debt measures the unsecured debt that will be discharged in bankruptcy; a measure of benefit of filing. As not filing

\footnotetext{
${ }^{12}$ See Kennickell et. at (1998).

${ }^{13}$ A more complete measure of costs would include both out-of-pocket filing costs, and future costs resulting from more restricted access to debt markets. Reliable data on these measures is not available. Adding a constant, of course, would not change the qualitative results.
} 
dominates filing when $d e b t-\max ($ wealth - exemption, 0$)$ is negative, the financial benefit from filing is truncated at 0 to yield the above formula.

To calculate financial benefit in the PSID, we use the same dataset as FHW.

For the SCF, we make the following adjustments. The SCF provides only region codes; state codes are not released in public data. To get a relative weight for each state in a region, we use Regional Economic Information System (REIS) from the Bureau of Economic Analysis. These state weights are based on the population of a state relative to the region in which it is included. These weights are used to compute the composite exemption level of a region.

Using Elias, Renauer, and Leonard (1999), we determine each state's exemption levels for 1998 for homestead equity in owner-occupied homes, equity in vehicles, personal property, and wildcard exemptions. We adjust for state level variables to the extent we can. For example, if a state doubles exemptions for married households, we do the same. For the fifteen states allowing residents to choose between state or federal exemptions, we take the larger of the exemptions. For households in states with an unlimited homestead exemption, we take the homestead exemption to be the average of home values in the entire sample.

The variable exemption is assumed to be the sum of these exemptions, because we do not observe a household's state of residence. The variable wealth is the sum of net worth of businesses a household owns, current values of the vehicles it owns, and value of real estate it owns.

To make the two datasets consistent with each other, we include a vector of demographic variables which may be related to households' filing decisions, such as age of household head, years of education of the head, family size, whether head owns their home and whether head owns business. Moreover, as adverse events variables, we include spell of unemployment, its squared term, whether the head is unemployed, whether the head's marital status is divorce, whether the head's health condition is poor. For the PSID dataset, these variables are calculated using the values of corresponding variables in the year prior to their bankruptcy. For the SCF data, we include only the region dummies rather than macro information to capture the local fixed effects due to the lack of information regarding state of residency. 


\subsection{Simple Probit model}

Let's first consider a simple Probit regression, similar to FHW's specification.

$$
\text { file }=1(\gamma f b+X \beta+\alpha A E+u>0)
$$

This specification explores the strategic filing and adverse event hypotheses by running the Probit regression of whether households file for bankruptcy (file) as a function of their potential financial benefit, $f b$, from filing, their personal and state characteristics $X$, and the adverse events they encountered in the previous year, $A E$.

As described above, the strict interpretation focuses on the significance of the coefficients on financial benefit and on adverse events. If strategic filing hypothesis is true, the coefficients of financial benefit should be positive and significant while the adverse event variables should not be significant. If adverse event hypothesis is true, then adverse event variables should be positive and significant while the coefficient of financial benefit should be insignificant.

Table 2 illustrates this simple specification with PSID data and SCF data. ${ }^{14}$ (For ease of comparison, we keep the other variables same as those in FHW.) As shown in table 2, using PSID data, the coefficients on the variables are comparable to those reported in FHW. In particular, financial benefit affects the filing decision positively and highly significantly, and its squared term is highly significant. Among statistically significant adverse events, divorce is positive but only marginally significant. Moreover, using SCF data, financial benefit continues to be positive and highly significant, but its squared term is not significant any more. The coefficient on divorce remains positive, but is highly significant.

Thus, using the strict interpretation, and the simple Probit model, the PSID dataset provides support for the strategic hypothesis while the SCF dataset provides support for both the strategic and the adverse events hypothesis.

\subsection{One-type model}

\footnotetext{
${ }^{14}$ For all estimates, $*$ indicates significance at 90 percent, $* *$ at 95 percent, and $* * *$ at 99 percent.
} 
Given the limitation of the strict interpretation, we propose to test the endogeneity of financial benefit by jointly estimating financial benefit and the bankruptcy decision. We allow the bankruptcy decision and financial benefit decision to be determined jointly. The basic empirical model here is:

$$
\begin{gathered}
\text { file }^{*}=X \beta+\gamma \ln (f b+1)+u,\left\{\begin{array}{lll}
\text { file }=1 & \text { if } & \text { file } \\
\text { file }=0 & \text { if } & \text { file } \\
* & & \\
\ln \left(f b^{*}+1\right)=X \delta+\mu A E+v,
\end{array}\right. \\
\left\{\begin{array}{lll}
f b=f b^{*} & \text { if } & f b^{*} \geq 0 \\
f b=0 & \text { if } & f b^{*}<0
\end{array}\right.
\end{gathered}
$$

Notice that endogeneity of $\ln (f b+1)$ is equivalent to whether the error terms $u$ and $v$ are correlated. The key difference between this model and FHW's specification is the role of the set of adverse events, $A E$. Here, $A E$ no longer directly affects a person's bankruptcy decision. Instead, it serves as the set of instrumental variables that directly affects the financial benefits, $f b$, in (4). Since adverse events are exogenous to a household's bankruptcy decision, they act more as a negative shock to a household's income/wealth.

Another minor difference between these two models is that the logarithm of financial benefit is used here while FHW use the level of financial benefits. As $f b$ depends on the wealth level, it is most likely to exhibit a log-normal distribution, although censored at zero. With a logarithm transformation, we will assume that $v$ is normally distributed.

Let $\operatorname{Var}(u)=1, \operatorname{Var}(v)=\sigma_{v}^{2}$, and assume the relationship between $u$ and $v$ as follows:

$$
u=\theta v+\varepsilon,
$$

where $\operatorname{Cov}(v, \varepsilon)=0$, and $\operatorname{Var}(\varepsilon)=1-\theta^{2} \sigma_{v}^{2}$. In this version, the endogeneity of $\ln (\mathrm{fb}+1)$ is equivalent to the hypothesis that the parameter $\theta=0$. The probability a household files when financial benefit is zero is given by

$$
\operatorname{Pr}(\text { file }=1, \ln (f b+1)=0)=\int_{-\infty}^{-X \delta-\mu A E} \Phi\left(\frac{X \beta+\theta v}{\sqrt{1-\theta^{2} \sigma_{v}^{2}}}\right) \frac{1}{\sigma_{v}} \phi\left(\frac{v}{\sigma_{v}}\right) d v
$$


and accordingly, the probability it does not file when financial benefit is zero is given by

$$
\operatorname{Pr}(\text { file }=0, \ln (f b+1)=0)=\int_{-\infty}^{-X \delta-\mu A E} \Phi\left(-\frac{X \beta+\theta v}{\sqrt{1-\theta^{2} \sigma_{v}^{2}}}\right) \frac{1}{\sigma_{v}} \phi\left(\frac{v}{\sigma_{v}}\right) d v
$$

Similarly,

$$
\begin{aligned}
& \operatorname{Pr}(\text { file }=1, \ln (f b+1)) \\
& =\Phi\left(\frac{X \beta+\gamma \ln (f b+1)+\theta(\ln (f b+1)-X \delta-\mu A E)}{\sqrt{1-\theta^{2} \sigma_{v}^{2}}}\right) \frac{1}{\sigma_{v}} \phi\left(\frac{\ln (f b+1)-X \delta-\mu A E}{\sigma_{v}}\right), \text { and }
\end{aligned}
$$

$$
\operatorname{Pr}(\text { file }=0, \ln (f b+1))
$$

$$
=\left[1-\Phi\left(\frac{X \beta+\gamma \ln (f b+1)+\theta(\ln (f b+1)-X \delta-\mu A E)}{\sqrt{1-\theta^{2} \sigma_{v}^{2}}}\right)\right] \frac{1}{\sigma_{v}} \phi\left(\frac{\ln (f b+1)-X \delta-\mu A E}{\sigma_{v}}\right) \text {. }
$$

The log-likelihood function over the sample is given by

$$
\begin{gathered}
l=\sum_{\text {file }=0, \ln (f b+1)>0} \ln (\operatorname{Pr}(\text { bank }=0, \ln (f b+1)>0))+\sum_{\text {file }=1, \ln (f b+1)>0} \ln (\operatorname{Pr}(\text { bank }=1, \ln (f b+1)>0)) \\
+\sum_{\text {file }=0, \ln (f b+1)=0} \ln (\operatorname{Pr}(\text { bank }=0, \ln (f b+1)=0))+\sum_{\text {file }=1, \ln (f b+1)=0} \ln (\operatorname{Pr}(\text { bank }=1, \ln (f b+1)=0))
\end{gathered}
$$

Estimation results are presented in tables 3 and $4 .{ }^{15}$ We find that using either PSID data (table 3 ), or SCF data (table 4), the estimated parameter $\theta$ is not statistically different from zero, consistent with the adverse events hypothesis. At the same time, log financial benefit has a positive and highly significant effect on the decision to file for bankruptcy in both datasets.

Both datasets confirm the view that adverse events may affect financial benefit. In the PSID data (table 3), health shocks and period of unemployment increase financial benefit highly significantly, whereas a switch from working to not working (no work dummy) decreases financial benefit. In the SCF data (table 4), divorce increases financial benefit highly

\footnotetext{
${ }^{15}$ We apply a log transformation to financial benefit, because this variable exhibits a distribution that is similar to log-normal but is left-censored at zero. In particular, we use $\log ($ financial benefit $+\$ 1$ ). This is to capture the characteristics of censored data at zero. The transformed variable is also left-censored at zero.
} 
significantly, whereas not working decreases financial benefit. In both datasets, period of unemployment increases financial benefit (highly significantly in the PSID data, but insignificantly in the SCF data), and the effect of its square term is negative.

\subsection{Two-type model}

To inquire into the possibility of both types of behavior existing simultaneously, we extend the analysis to allow for heterogeneity in types by proposing a two-type model.

Let a random variable $T=1$ if a person is a strategic type, and $T=2$ if a person is a non-strategic (or adverse events) type. For simplicity, we let

$$
\operatorname{Pr}(T=1)=\Phi(W \alpha) \text {, and } \operatorname{Pr}(T=2)=1-\Phi(W \alpha) .
$$

$\Phi()$ is the normal distribution function and $W$ is a set of type-determinant variables, which will be discussed more in detail later in this subsection. For each type, we allow that their characteristics have different impact factor when they make the filing decisions, as follows.

When $T=1$, the filing equation is file $=1\left(X \beta_{1}+\gamma_{1} \ln (f b+1)+u_{1}>0\right)$.

When $T=2$, the filing equation is file $=1\left(X \beta_{2}+\gamma_{2} \ln (f b+1)+u_{2}>0\right)$.

We normalize the variances of the error terms for both types to be 1, i.e. $\operatorname{Var}\left(u_{1}\right)=\operatorname{Var}\left(u_{2}\right)=1$.

Similarly, we allow behavior in accumulating debt or financial benefit to be different for each type. For the strategic type, financial benefit is assumed to be endogenous, and for the adverse events type, it is assumed to be exogenous. Thus, for the strategic type,

$$
\ln \left(f b^{*}+1\right)=X \delta_{1}+\mu_{1} A E+v_{1}, \quad\left\{\begin{array}{lll}
f b=f b^{*} & \text { if } & f b^{*}>0 \\
f b=0 & \text { if } & f b^{*}<0
\end{array} \text { and } u_{1}=\theta_{1} v_{1}+\varepsilon_{1}\right.
$$

where the variance for the error term $\varepsilon_{1}$ is $\operatorname{Var}\left(\varepsilon_{1}\right)=1-\theta_{1}^{2} \sigma_{v 1}^{2}$, if we assume that $\operatorname{Var}\left(v_{1}\right)=\sigma_{v 1}^{2}$.

For the adverse events type, 


$$
\ln \left(f b^{*}+1\right)=X \delta_{2}+\mu_{2} A E+v_{2}, \quad\left\{\begin{array}{lll}
f b=f b^{*} & \text { if } & f b^{*}>0 \\
f b=0 & \text { if } & f b^{*}<0
\end{array} .\right.
$$

if our assumption about adverse event type is true, then $\operatorname{Cov}\left(u_{2}, v_{2}\right)=0$. In empirical estimation, we will allow the possibility that $\operatorname{Cov}\left(u_{2}, v_{2}\right) \neq 0$, and estimate their correlation. That is we assume $u_{2}=\theta_{2} v_{2}+\varepsilon_{2}$ and test whether $\theta_{2}$ is significantly different from zero.

Notice that the joint density of $($ bank, $\ln (f b+1))$ consists of four parts, $($ bank $=0, \ln (f b+1)=0)$, $($ bank $=1, \ln (f b+1)=0),($ bank $=0, \ln (f b+1))$, and $($ bank $=1, \ln (f b+1))$. In the last two cases $\ln (f b+1)$ is positive and continuous. The density function for each of the four cases is given in Appendix $B$.

The model suggested here belongs to the class of the mixture density models. A well-known necessary identification condition of the model requires the exclusion restriction, i.e., the set $W$ is different from $X$ and $A E$. Henry, Kitamura, and Salanié (2010) show that a correlation between $W$ and $T$ and the independence between $W$ and the error terms $\left(u_{1}\right.$ and $\left.u_{2}\right)$ in equations (6.1) and (6.2) are sufficient to identify the model up to a linear transformation non-parametrically. When the set $W$ has more than one variable, Henry, Kitamura, and Salanié (2010) and Gan, Huang, and Mayer (2011) show that a using the full set of $W$ and a subset of $W$ would both produce consistent estimates of parameters of the model except the coefficients to determine the type. A Hausman-type specification test can be implemented by comparing estimates using the full set of $W$ with those using a subset of $W .{ }^{16}$ This test is similar to an overidentification test in the instrumental variable models. A failure of rejection provides supporting evidence of the appropriateness of the $W$ and the specification of the model.

Here we suggest a set of variables that includes number of credit cards, logarithm of income, whether the person is risk averse, ${ }^{17}$ and whether the person shops around for the best term ${ }^{18}$. These variables are not in the set of $X$ that directly explains the bankruptcy decision.

\footnotetext{
${ }^{16}$ Gan, Huang, and Mayer (2011) provide an economic interpretation of this type of mixture density model.

${ }^{17}$ SCF asks its respondents: "Which of the statements on this page comes closest to the amount of financial risk that you are willing to take when you save or make investments?" and we define the variable "risk averse" to be one if the respondent chooses "not willing to take any financial risks".
} 
Our prior is that a person's credit worthiness may be an important factor in determining her type. A better credit-scored person may be less likely to be the strategic type. Since credit scores are not available in the data set, several variables that are related to credit scores are used. Therefore, the person with fewer numbers of cards is more likely to belong to the strategic type. Moreover, it is reasonable to postulate that a person who shops around is more frugal, and hence less likely to take on debt, and therefore, less focused on planning for bankruptcy. Thus, a person who shops around more may be less likely to be a strategic type.The effect of risk aversion on determining the type is unclear. It is not necessarily the case that a more risk-averse person is more likely to file for bankruptcy. ${ }^{19}$ The summary statistics of these four variables can be found in table 1. All variables have substantial variations.

Table 5 shows estimation results for this model, using SCF data. ${ }^{20}$ This framework provides the clearest distinctions between the two models, as described in section 2 above.

One important distinction between the two models is endogeneity or exogeneity of financial benefit. Although we allow for the possibility of non-zero correlation between the error terms in the bankruptcy model and the financial benefit model for both types, only the strategic type exhibits a statistically significant (at the 95 percent level) correlation, at -5390 (0.3011) (0.3159), while the correlation for the adverse events type is statistically insignificant, at 0.2505 (0.4554). Thus, financial benefit is endogenous to the bankruptcy decision for strategic types, and exogenous for adverse events types, as predicted by the hypothesis.

The coefficient on log of financial benefit is positive and highly significant for the strategic type, at $0.2282(0.0498)$ but for adverse events type, this coefficient is negative and insignificant, at

\footnotetext{
${ }^{18}$ SCF asks its respondents: "When making major saving and investment decisions, some people shop around for the very best terms while others don't. What number would you be on the scale?" And this variable is a number between 1 and 5, the larger the number, the greater the shopping.

${ }^{19}$ Gan and Mosquera (2008) (Appendix ) show that a more risk averse person may or may not have a higher probability of default, depending on relative current income and future income.

${ }^{20}$ The two-type model could only be estimated using SCF data, partly because PSID does not have the typedetermination variables similar to those in SCF.
} 
$0.0155(0.0881)$ The coefficient for the strategic type is larger than the coefficient for the adverse events type, as predicted by the hypothesis.

Similarly, variables for adverse events (other than health problems) have the same effect on both types, but with a larger absolute effect for strategic types. Not working lowers financial benefit, increasing unemployment spell increases financial benefit, and divorce increases financial benefit..Health problems present a mixed picture, a positive (and insignificant) effect on financial benefit for adverse types, but decreasing (and insignificant) effect for strategic types. These results document a financial-benefits channel for adverse events.

The last panel in table 5 shows that fewer numbers of credit cards increases the chance of strategic behavior, as does an increase in risk aversion. Consumers who shop around more are more likely to be strategic type. A lower income also increases the chance of strategic behavior.

As shown in table 6 , the average probability of being a strategic type is 0.1675 . This provides additional confirmation for the exogeneity of financial benefit in the one-type model.

For additional analysis of the two types, we divide the population into two groups. A household is of strategic type, if its type probability is greater than 0.5, and is of adverse events type otherwise. According to this criterion, 808 households are strategic type and3497 households are adverse events type, as shown in table 6.

Notably, on average, a strategic type has a 3.47\% chance to file for bankruptcy, more than 4 times higher than the $0.77 \%$ chance of the adverse type. This greater filing probability is consistent with the empirical prediction of the model in section 2. Similarly, in terms of the predicted probabilities, a strategic type is expected to have $9.08 \%$ chance to file for bankruptcy while the adverse events type would have $0.55 \%$ chance to file for bankruptcy.

Moreover, the two types exhibit different levels of financial benefits. The average level of log of financial benefit is 2.4406 for the strategic type, about 33.34 percent larger than 1.8303 for the adverse events type. The larger financial benefit for strategic type is again consistent with the prediction of the model. Similarly, on average, about $30.69 \%$ of strategic type consumers have strictly positive financial benefit, as compared to $20.81 \%$ of adverse events type. 
As shown in table 6, the predicted probability of filing for bankruptcy is higher than actual for both types. One possible explanation is that financial benefit from filing for bankruptcy is heavily censored at zero (about 80 percent of the financial benefit calculations take the value of zero), and the predicted value is close to the true data of the percentage of those zeroes. This may also provide a reason why the bias of mean of log financial benefit is so large.

Table 7 shows the effects of hypothesized changes in particular variables on the probability of filing. ${ }^{21}$ For example, if financial benefit goes up by $\$ 1,000$, and all other characteristics are held constant at sample means, the average strategic type's filing probability goes up 0.0187 percentage points (equivalently, the filing probability increases by 0.0187 ), that of an adverse events type goes up negligibly, and the total filing probability goes up about 0.0037 percentage points. In terms of a percentage change in the filing rate, filing rates for strategic types go up by 53.89 percent, those for adverse types go up by 9.09 percent, and total filings go up by 29.07 percent. ${ }^{22}$ Similarly, if percentage of home fully paid increases by 5 percentage points, the filing rates of strategic types go down about 14.99 percent, those of adverse types go up 3.90 percent, and the overall filing rate goes down about 4.86 percent.

Our framework allows estimates of the effects of adverse events on filing probabilities through the channel of financial benefit. Table 8 presents some of these effects. If the average spell of unemployment goes down by 0.5 week, the filing rate of strategic types goes down 80.69 percent, that of adverse events goes down negligibly, and the overall filing rate goes down 37.12 percent. A 5 percentage point decrease in the proportion of people not working leads to an increase in filing rate of strategic types by 24.78 percent, a negligible increase for adverse types, and an 11.47 percent increase in the overall filing rate. Similarly, a decrease of 5 percentage points in divorce, lowers the overall filing rate by about 6.51 percent. Notice that the

\footnotetext{
${ }^{21}$ The columns for percentage point marginal effect show the change in filing probability. The column labeled "Total" gives the weighted average of the changes, using probability of strategic type as 0.1566 and that of adverse events type as 0.8434 .

${ }^{22}$ The last three columns in table 7 translate the marginal effects into the corresponding percentage change in the filing rate, as follows: divide the marginal effect of the strategic type by the filing probability of strategic type, which is 0.0337 in the sample, that of adverse type by their filing probability, which is 0.008 , and the total by the total filing probability, which is 0.01278 .
} 
comparatively smaller effects for adverse type (as compared to strategic type) are in part due to their much lower responsiveness to financial benefit in the bankruptcy equation.

Finally, table 9 lists the Hausman specification test suggested in Henry, Kitamura, and Salanié (2010), and Gan, Huang, and Mayer (2011). As described in table 5, the full set of type determination variables includes $\ln$ (income), number of credit cards, an indicator for risk aversion, and whether the person shops around for the best term. The first column in table 9 presents estimates of several key variables of the model using the full set of $W$. The second to the fourth columns have the estimation results without "shop around", "risk averse" and "shop around", and "log income" and "shop around" variables, respectively. The tests show the difference of the coefficients for all parameters (except type-determination variables in $W$ ) from the full set of $W$ and from a subset of $W$ are not statistically different. This result provides supports the current two-type setup instead of a setup with three ore more types, and the appropriateness of $W$.

\section{Conclusions}

The adverse events and strategic filing hypotheses have received particular attention in the debate on bankruptcy. Existing work proposes to distinguish between these hypotheses in a "strict" manner, which does not allow adverse events to affect probability of filing through the channel of financial benefits.

We propose testing for endogeneity of financial benefit as a distinguishing feature between the hypotheses. Financial benefit is endogenous to the filing decision for strategic types, and exogenous for adverse events types. This test allows adverse events to affect probability of filing in both hypotheses through the channel of financial benefit.

Using a single-type model, we show that both the PSID and the SCF data support the adverse events hypothesis.

Extending the analysis to allow for the more realistic case of both types existing simultaneously, we propose and estimate a mixture-density type model with two types. We find evidence of both types of behavior in the data. In particular, financial benefit is endogenous for the strategic type 
and exogenous for the adverse events type. On average, about 16 percent of the sample is strategic type, and 84 percent is adverse events type, providing support for the exogeneity of financial benefit in the one-type model. These results show a role for both hypotheses. A specification test provides supporting evidence of the current model and the appropriateness of the exclusion restriction.

The estimates here are broadly consistent with theoretical predictions: the probability of filing and the financial benefit from filing are both larger for strategic type than for adverse events type. There is some evidence of a "financial-benefits" channel of the effect of adverse events on filing probability. We also find that marginal effect of financial benefit on filing probability is larger for the strategic type than for the adverse events type.

Notably, the models here are simple, and do not capture all relevant aspects of the bankruptcy decision. Similarly, data limitations prevent more thorough investigation of these ideas. Additional research on both aspects would help understand the bankruptcy decision in more detail. 
Table 1: Summary Statistics

\begin{tabular}{|c|c|c|c|c|}
\hline \multirow[t]{2}{*}{ Variables } & \multicolumn{2}{|c|}{ PSID data } & \multicolumn{2}{|c|}{ SCF data } \\
\hline & Mean value & $\begin{array}{l}\text { Standard } \\
\text { deviation }\end{array}$ & $\begin{array}{l}\text { Mean } \\
\text { value }\end{array}$ & $\begin{array}{l}\text { Standard } \\
\text { deviation }\end{array}$ \\
\hline Number of bankruptcy filings & \multicolumn{2}{|c|}{254} & \multicolumn{2}{|c|}{55} \\
\hline Financial benefit & $\$ 1,411$ & $\$ 10,523$ & $\$ 3,991$ & $\$ 26,001$ \\
\hline $\log ($ financial benefit +1 ) & 1.64 & 3.24 & 1.95 & 3.69 \\
\hline Those file for bankruptcy & 3.65 & 4.26 & 6.78 & 4.38 \\
\hline $\log ($ unsecured debt +1$)$ & 3.85 & 3.94 & 4.35 & 4.45 \\
\hline Those file for bankruptcy & 5.74 & 3.96 & 5.88 & 3.96 \\
\hline Household labor income & $\$ 26,552$ & $\$ 32,672$ & $\$ 43,035$ & $\$ 37,967$ \\
\hline Age of household head & 44.19 & 15.96 & 49.84 & 16.52 \\
\hline Years of education of household head & 12.43 & 5.10 & 13.74 & 2.90 \\
\hline Family size & 2.90 & 1.55 & 2.65 & 1.44 \\
\hline Own home & 0.59 & 0.49 & 0.70 & 0.46 \\
\hline Self employed/own business & 0.11 & 0.31 & 0.25 & 0.44 \\
\hline Head is divorced & 0.03 & 0.18 & 0.13 & 0.33 \\
\hline Head is unemployed & 0.06 & 0.23 & 0.23 & 0.42 \\
\hline Weeks of unemployment of head & 6.76 & 2.01 & 2.39 & 6.34 \\
\hline Head has health problem & 0.07 & 0.26 & 0.04 & 0.19 \\
\hline $\ln$ (income) & & & 10.89 & 1.98 \\
\hline Number of credit cards & & & 4.44 & 4.36 \\
\hline Risk averse & & & 0.30 & 0.46 \\
\hline Shop around & & & 3.03 & 1.38 \\
\hline Total number of observations & & & & \\
\hline
\end{tabular}


Table 2: Simple Probit model

\begin{tabular}{|c|c|c|c|c|}
\hline & \multicolumn{2}{|c|}{ PSID data } & \multicolumn{2}{|c|}{ SCF data } \\
\hline & $\begin{array}{l}\text { without adverse } \\
\text { event variables }\end{array}$ & $\begin{array}{l}\text { with adverse } \\
\text { event variables }\end{array}$ & $\begin{array}{l}\text { without adverse } \\
\text { event variables }\end{array}$ & $\begin{array}{c}\text { with adverse event } \\
\text { variables }\end{array}$ \\
\hline financial benefit & $\begin{array}{l}0.00006^{* * * *} \\
(0.00001)\end{array}$ & $\begin{array}{l}0.00006^{* * *} \\
(0.00001)\end{array}$ & $\begin{array}{c}0.00002^{* * *} \\
(6.6 \mathrm{e}-6)\end{array}$ & $\begin{array}{l}0.00002^{* * *} \\
(6.85 \mathrm{e}-6)\end{array}$ \\
\hline $\begin{array}{l}\text { financial benefit } \\
\text { squared }\end{array}$ & $\begin{array}{c}-1.04 \mathrm{e}-9 * * * \\
(4.04 \mathrm{e}-10)\end{array}$ & $\begin{array}{l}-1.03 \mathrm{e}-9 * * * \\
(3.99 \mathrm{e}-10)\end{array}$ & $\begin{array}{l}-1.09 \mathrm{e}-10 \\
(6.98 \mathrm{e}-11)\end{array}$ & $\begin{array}{l}-1.08 \mathrm{e}-10 \\
(7.36 \mathrm{e}-11)\end{array}$ \\
\hline lagged bankruptcy rate & $\begin{array}{l}5.95905^{* *} \\
(2.67377)\end{array}$ & $\begin{array}{l}5.62294^{* *} \\
(2.68448)\end{array}$ & & \\
\hline household labor income & $\begin{array}{l}-4.98 \mathrm{e}-6 * * * \\
(1.41 \mathrm{e}-6)\end{array}$ & & $\begin{array}{c}-3.46 \mathrm{e}-6^{* *} \\
(1.80 \mathrm{e}-6)\end{array}$ & \\
\hline reduction in income & $\begin{array}{c}-2.17 \mathrm{e}-6 * * * \\
(5.92 \mathrm{e}-7)\end{array}$ & & $\begin{array}{l}-3.06 \mathrm{e}-6^{* * *} \\
(1.02 \mathrm{e}-6)\end{array}$ & \\
\hline age of household head & $\begin{array}{c}0.02917 * * \\
(0.0137)\end{array}$ & $\begin{array}{c}0.01846 \\
(0.01306)\end{array}$ & $\begin{array}{c}0.0285 \\
(0.0327)\end{array}$ & $\begin{array}{l}-0.00296 \\
(0.0319)\end{array}$ \\
\hline age squared & $\begin{array}{c}-0.00048^{* * *} \\
(0.00016)\end{array}$ & $\begin{array}{c}-0.00036^{* *} \\
(0.00015)\end{array}$ & $\begin{array}{l}-0.00035 \\
(0.00036)\end{array}$ & $\begin{array}{l}-0.00003 \\
(0.0003)\end{array}$ \\
\hline education & $\begin{array}{c}-0.02981 * * * \\
(0.01155)\end{array}$ & $\begin{array}{c}-0.03879 * * * \\
(0.01097)\end{array}$ & $\begin{array}{c}0.0088 \\
(0.0218)\end{array}$ & $\begin{array}{l}-0.0101 \\
(0.0218)\end{array}$ \\
\hline family size & $\begin{array}{l}0.03736^{* *} \\
(0.01673)\end{array}$ & $\begin{array}{l}0.03228^{*} \\
(0.01669)\end{array}$ & $\begin{array}{c}0.0687 * * \\
(0.0332)\end{array}$ & $\begin{array}{c}0.0951^{* * *} \\
(0.0363)\end{array}$ \\
\hline own business & $\begin{array}{l}0.04037 \\
(0.0918)\end{array}$ & $\begin{array}{c}0.09489 \\
(0.09147)\end{array}$ & $\begin{array}{l}-0.1608 \\
(0.2630)\end{array}$ & $\begin{array}{l}-0.1661 \\
(0.2400)\end{array}$ \\
\hline own home & $\begin{array}{l}-0.1371^{*} \\
(0.07437)\end{array}$ & $\begin{array}{c}-0.19982 * * * \\
(0.06757)\end{array}$ & $\begin{array}{l}-0.1084 \\
(0.1553)\end{array}$ & $\begin{array}{l}-0.1663 \\
(0.1484)\end{array}$ \\
\hline lawyers per capita & $\begin{array}{l}-0.7776 \\
(0.74456)\end{array}$ & $\begin{array}{l}-0.98042 \\
(0.73636)\end{array}$ & & \\
\hline $\begin{array}{l}\text { county unemployment } \\
\text { rate }\end{array}$ & $\begin{array}{c}0.09337 \\
(0.10457)\end{array}$ & $\begin{array}{c}0.10714 \\
(0.11386)\end{array}$ & & \\
\hline state income growth & $\begin{array}{c}-2.39603 * * \\
(1.19746)\end{array}$ & $\begin{array}{l}-2.23304^{*} \\
(1.18386)\end{array}$ & & \\
\hline state income deviation & $\begin{array}{l}-0.12465 \\
(0.08725)\end{array}$ & $\begin{array}{l}-0.12976 \\
(0.08821)\end{array}$ & & \\
\hline divorce & & $\begin{array}{l}0.23206^{*} \\
(0.13196)\end{array}$ & & $\begin{array}{c}0.6434 * * * \\
(0.1578)\end{array}$ \\
\hline $\begin{array}{l}\text { period of } \\
\text { unemployment }\end{array}$ & & $\begin{array}{c}0.0134 \\
(0.02435)\end{array}$ & & $\begin{array}{l}-0.0066 \\
(0.0110)\end{array}$ \\
\hline health problem & & $\begin{array}{c}0.09265 \\
(0.11733)\end{array}$ & & $\begin{array}{l}-0.1097 \\
(0.3149)\end{array}$ \\
\hline state fixed effects & yes & yes & yes & yes \\
\hline year fixed effects & yes & yes & no & no \\
\hline constant & $\begin{array}{c}-2.3797 * * * \\
(0.71384)\end{array}$ & $\begin{array}{c}-2.23563 * * * \\
(0.75997)\end{array}$ & $\begin{array}{c}-3.0914 * * * \\
(0.8504)\end{array}$ & $\begin{array}{c}-2.6235 * * * \\
(0.8231)\end{array}$ \\
\hline
\end{tabular}


Table 3: One-type model (PSID data)

\begin{tabular}{|c|c|c|}
\hline variables & coefficient & std err \\
\hline Correlation between the two error terms $\theta$ & -0.1423 & 0.3562 \\
\hline \multicolumn{3}{|c|}{ Bankruptcy equation } \\
\hline Log financial benefit & $0.0791 * * *$ & 0.0321 \\
\hline Age & 0.0146 & 0.0124 \\
\hline Age squared & $-0.000264 * *$ & .000138 \\
\hline Lagged bankruptcy filing rate & $5.805^{* * *}$ & 2.791 \\
\hline Education & $-0.0204 * * *$ & 0.0098 \\
\hline Family size & 0.0223 & 0.0160 \\
\hline Own business & 0.0531 & 0.0837 \\
\hline Own home & -0.05835 & 0.0565 \\
\hline Lawyer per capita & -0.0389 & 0.7598 \\
\hline Growth rate of income & -1.915 & 1.344 \\
\hline State income deviation & $-0.1424 *$ & 0.0774 \\
\hline State and time dummies & yes & \\
\hline constant & $-2.1573 * * *$ & 0.5716 \\
\hline \multicolumn{3}{|c|}{ Financial benefit equation } \\
\hline \multicolumn{3}{|l|}{ Excluded adverse event variables } \\
\hline Health & $1.924 * * *$ & 0.2295 \\
\hline Divorce & 0.3603 & 0.3356 \\
\hline No work & $-1.358 * * *$ & 0.2552 \\
\hline Period of unemployment & $0.7635^{* * *}$ & 0.1968 \\
\hline Period of unemployment squared & $-0.0475 * * *$ & 0.0123 \\
\hline \multicolumn{3}{|l|}{ Other control variables } \\
\hline Age & $-0.1338 * * *$ & 0.0261 \\
\hline Age squared & $-0.00067 * * *$ & 0.00027 \\
\hline Lagged bankruptcy filing rate & -3.523 & 8.545 \\
\hline Education & $-0.0305^{* * *}$ & 0.0147 \\
\hline Family size & $0.4157 * * *$ & 0.0398 \\
\hline Own business & $-3.204 * * *$ & 0.2238 \\
\hline Own home & $-3.215^{* * *}$ & 0.1332 \\
\hline Lawyer per capita & $-2.942 *$ & 1.618 \\
\hline Growth rate of income & $-2.302 * * *$ & 3.439 \\
\hline State income deviation & $-0.2989 * * *$ & 0.1997 \\
\hline State and time dummies & yes & \\
\hline Constant & $-0.8642 * *$ & 1.6281 \\
\hline Standard deviation of error term & $3.2073 * * *$ & 0.0127 \\
\hline Log-likelihood & -61773 & \\
\hline
\end{tabular}


Table 4: One-type model (SCF data)

\begin{tabular}{|c|c|c|}
\hline variables & coefficient & std \\
\hline Correlation between the two errors $\theta$ & -0.2845 & 0.2032 \\
\hline \multicolumn{3}{|c|}{ Bank equation } \\
\hline Log financial benefit & $0.1377 * * *$ & 0.0360 \\
\hline Age & $0.0447^{*}$ & 0.0240 \\
\hline Age squared & $-0.0004^{*}$ & 0.0002 \\
\hline Family size & 0.0551 & 0.0394 \\
\hline Own home & 0.0190 & 0.1285 \\
\hline Own business & -0.2000 & 0.1981 \\
\hline Years of education & 0.2250 & 0.1643 \\
\hline Years of education squared & -0.0092 & 0.0064 \\
\hline Region dummies & Yes & \\
\hline constant & $-5.5722 * * *$ & 1.2724 \\
\hline \multicolumn{3}{|c|}{ Financial benefit equation } \\
\hline \multicolumn{3}{|l|}{ Excluded adverse variables } \\
\hline Health & 1.0410 & 1.1136 \\
\hline No work & $-4.6296 * * *$ & 0.8369 \\
\hline Period of unemployment & 0.1472 & 0.1248 \\
\hline Period of unemployment squared & -0.0027 & 0.0033 \\
\hline Divorce & $2.6813 * * *$ & 0.5950 \\
\hline \multicolumn{3}{|l|}{ Other control variables } \\
\hline Age & -0.0628 & 0.0845 \\
\hline Age squared & -0.0014 & 0.0009 \\
\hline Family size & 0.2121 & 0.1516 \\
\hline Own home & $-5.1205 * * *$ & 0.4900 \\
\hline Own business & $-7.5376 * * *$ & 0.6801 \\
\hline Years of education & 0.5068 & 0.3661 \\
\hline Years of education squared & $-0.0483 * * *$ & 0.0152 \\
\hline Region dummies & yes & \\
\hline Constant & $7.8295^{* *}$ & 3.1007 \\
\hline Standard deviation of error term & $9.3535^{* * *}$ & 0.1262 \\
\hline Log-likelihood & -4812.66 & \\
\hline
\end{tabular}


Table 5: Two-type model (SCF)

\begin{tabular}{|c|c|c|c|c|}
\hline & coefficient & sd & coefficient & sd \\
\hline & \multicolumn{2}{|c|}{ Strategic type } & \multicolumn{2}{|c|}{ Adverse event type } \\
\hline Correlation b/w two errors $\theta$ & $-0.5390 *$ & 0.3011 & 0.2505 & 0.4554 \\
\hline \multicolumn{5}{|c|}{ Bankruptcy equation } \\
\hline $\log (f b+1)$ & $0.2282 * * *$ & 0.0498 & 0.0155 & 0.0881 \\
\hline Age & 0.0316 & 0.0352 & 0.0984* & 0.0732 \\
\hline Age squared & -0.0003 & 0.0003 & $-0.0013 * *$ & 0.0008 \\
\hline Family size & -0.0406 & 0.0720 & $0.0962 * *$ & 0.0604 \\
\hline Own home & -0.2916 & 0.2760 & 0.3923 & 0.3208 \\
\hline Years of education & $0.9403 *$ & 0.6171 & 0.0058 & 0.1639 \\
\hline Years of education ${ }^{2}$ & -0.0295 & 0.0226 & -0.0032 & 0.0072 \\
\hline Constant & $-9.8251 * *$ & 4.3525 & -4.0811 & 2.0682 \\
\hline \multicolumn{5}{|c|}{ IV equation (dependent variable $=\log ($ financial benefit $+\$ 1)$ ) } \\
\hline \multicolumn{5}{|c|}{ Excluded adverse event variables } \\
\hline Health problem & -1.4769 & 2.3707 & 2.9358 & 1.5140 \\
\hline No work & $-7.0502 * *$ & 2.1893 & $-1.8104 * * *$ & 1.0601 \\
\hline Period of unemployment & 3.5597 & 1.5271 & $0.4280 * *$ & 0.1526 \\
\hline Period of unemployment ${ }^{2}$ & -0.6169 & 0.2447 & -0.0071 & 0.0040 \\
\hline Divorce & $4.4111 * * *$ & 1.3443 & $2.4127 * * *$ & 0.7524 \\
\hline \multicolumn{5}{|l|}{ Other control variables } \\
\hline Age & $0.1834^{*}$ & 0.2079 & $-0.3441^{*}$ & 0.1075 \\
\hline Age squared & $-0.0024 * *$ & 0.0023 & 0.00004 & 0.0011 \\
\hline Family size & $0.9949 * * *$ & 0.3447 & -0.2095 & 0.1900 \\
\hline Own home & $-3.6837 *$ & 1.3781 & $7.9268 * * *$ & 0.6022 \\
\hline Years of education & -0.6020 & 0.7264 & $1.0059^{*}$ & 0.5567 \\
\hline Years of education ${ }^{2}$ & 0.0188 & 0.0359 & $-0.0797 * * *$ & 0.0218 \\
\hline Constant & -1.4351 & 6.3815 & $8.6807 * * *$ & 4.4264 \\
\hline Standard deviation of error & $8.7571^{* * *}$ & 0.2877 & 9.5600 & 0.1562 \\
\hline \multicolumn{5}{|c|}{ Type equation (strategic type $=1$ ) } \\
\hline $\ln$ (income) & \multicolumn{2}{|c|}{$-0.6032 * * *$} & \multicolumn{2}{|c|}{0.1104} \\
\hline Number of credit cards & \multicolumn{2}{|c|}{$-0.1518 * * *$} & \multicolumn{2}{|c|}{0.0239} \\
\hline Risk averse & \multicolumn{2}{|c|}{0.3554} & \multicolumn{2}{|c|}{0.2433} \\
\hline Shop around & \multicolumn{2}{|c|}{0.0218} & \multicolumn{2}{|c|}{0.0799} \\
\hline Constant & \multicolumn{2}{|c|}{$6.2026^{* * *}$} & \multicolumn{2}{|c|}{1.1365} \\
\hline Log-likelihood & \multicolumn{4}{|c|}{-4856.44} \\
\hline
\end{tabular}


Table 6: Comparing Strategic type and Adverse Events type

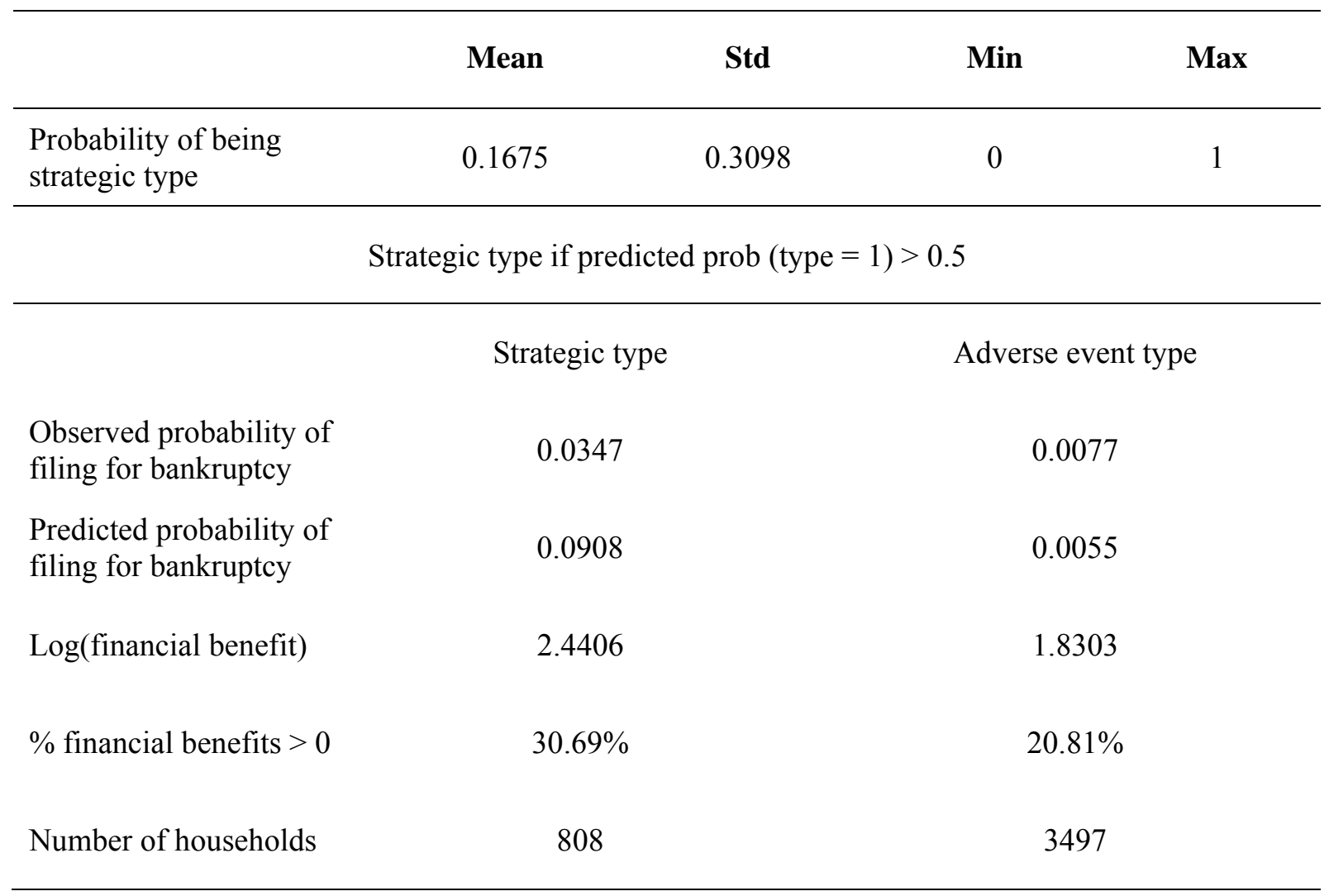


Table 7: SCF Predictions (Two type model)

\begin{tabular}{|c|c|c|c|c|c|c|c|c|}
\hline \multirow[t]{2}{*}{$\begin{array}{c}\text { Hypothesized } \\
\text { variable change }\end{array}$} & \multicolumn{2}{|c|}{$\begin{array}{c}\text { Mean effect on } \\
\text { log financial } \\
\text { benefit(std) }\end{array}$} & \multicolumn{3}{|c|}{$\begin{array}{c}\text { Percentage point } \\
\text { marginal effect(std) }\end{array}$} & \multicolumn{3}{|c|}{$\begin{array}{l}\text { Percentage change in the } \\
\text { filing rate }\end{array}$} \\
\hline & $\begin{array}{c}\text { Strategic } \\
\text { type }\end{array}$ & $\begin{array}{c}\text { Adverse } \\
\text { type }\end{array}$ & $\begin{array}{c}\text { Strategic } \\
\text { type }\end{array}$ & $\begin{array}{c}\text { Adverse } \\
\text { type }\end{array}$ & Total & $\begin{array}{c}\text { Strategic } \\
\text { type }\end{array}$ & $\begin{array}{c}\text { Adverse } \\
\text { type }\end{array}$ & Total \\
\hline $\begin{array}{l}\text { Financial benefit } \\
+\$ 1000 \text { from mean } \\
\$ 3990.772\end{array}$ & --- & --- & $\begin{array}{l}0.0187 \\
(0.0052)\end{array}$ & $\begin{array}{l}0.0007 \\
(0.0021)\end{array}$ & $\begin{array}{l}0.0037 \\
(0.0026)\end{array}$ & 53.89 & 9.09 & 29.07 \\
\hline $\begin{array}{l}\text { Financial benefit } \\
+\$ 1000 \text { from } \\
\text { positive mean } \$ \\
17602.74\end{array}$ & --- & --- & $\begin{array}{l}0.0045 \\
(0.0009)\end{array}$ & $\begin{array}{c}0.0002 \\
(0.0007)\end{array}$ & $\begin{array}{l}0.0009 \\
(0.0007)\end{array}$ & 12.97 & 2.60 & 7.20 \\
\hline $\begin{array}{l}\text { Age of household } \\
\text { head }+1 \text { years from } \\
\text { mean } 49.84\end{array}$ & $\begin{array}{l}0.1817 \\
(0.2070)\end{array}$ & $\begin{array}{l}-0.3417 \\
(0.1061)\end{array}$ & $\begin{array}{l}0.0139 \\
(0.0154)\end{array}$ & $\begin{array}{l}0.0114 \\
(0.0196)\end{array}$ & $\begin{array}{l}0.0118 \\
(0.0189)\end{array}$ & 40.06 & 148 & 92.48 \\
\hline $\begin{array}{l}\text { Family size }+0.5 \\
\text { from mean } 2.65\end{array}$ & $\begin{array}{l}0.4964 \\
(0.1725)\end{array}$ & $\begin{array}{l}-0.1025 \\
(0.0942)\end{array}$ & $\begin{array}{l}0.0118 \\
(0.0093)\end{array}$ & $\begin{array}{l}-3.8 \mathrm{e}-5 \\
(0.0001)\end{array}$ & $\begin{array}{l}0.0019 \\
(0.0016)\end{array}$ & 34.00 & -0.49 & 15.22 \\
\hline $\begin{array}{l}\text { Own home }+5 \% \\
\text { from mean } 70 \%\end{array}$ & $\begin{array}{l}-0.1838 \\
(0.0684)\end{array}$ & $\begin{array}{l}0.3964 \\
(0.0305)\end{array}$ & $\begin{array}{l}-0.0052 \\
(0.0018)\end{array}$ & $\begin{array}{l}0.0003 \\
(0.0005)\end{array}$ & $\begin{array}{l}0.0006 \\
(0.0007)\end{array}$ & -14.99 & 3.90 & -4.86 \\
\hline $\begin{array}{l}\text { Education }+1 \text { year } \\
\text { from mean } 13.74\end{array}$ & $\begin{array}{l}-0.6188 \\
(0.7293)\end{array}$ & $\begin{array}{c}0.9931 \\
(0.5493)\end{array}$ & $\begin{array}{l}0.0388 \\
(0.0886)\end{array}$ & $\begin{array}{l}0.0164 \\
(0.0314)\end{array}$ & $\begin{array}{l}0.0202 \\
(0.0410)\end{array}$ & 111.82 & 213 & 157.68 \\
\hline
\end{tabular}

We compute each household's estimated probability of bankruptcy under the hypothesized change, holding all other household characteristics at their mean. The marginal effect is the change in the probability of bankruptcy for that household. The column labeled "Total" gives the weighted average of the changes, using probability of strategic type as 0.1675 and that of adverse events type as 0.8325 . The last three columns translate the marginal effects into the corresponding percentage change in the filing rate, as follows: divide the marginal effect of the strategic type by the filing probability of strategic type, which is 0.0358 in the sample, that of adverse type by their filing probability, which is 0.007 , and the total by the total filing probability, which is 0.01278 . Figures in parentheses are bootstrapped standard errors, computed using 5,000 repetitions of the sample. 
Table 8: SCF Predictions (Two type model): Adverse Events

\begin{tabular}{|c|c|c|c|c|c|c|c|c|}
\hline \multirow[t]{2}{*}{$\begin{array}{l}\text { Hypothesized } \\
\text { variable change }\end{array}$} & \multicolumn{2}{|c|}{$\begin{array}{c}\text { Mean effect on } \\
\text { log financial } \\
\text { benefit } \\
\text { (std) }\end{array}$} & \multicolumn{3}{|c|}{$\begin{array}{c}\text { Percentage point } \\
\text { marginal effect (std) }\end{array}$} & \multicolumn{3}{|c|}{$\begin{array}{c}\text { Percentage change in the } \\
\text { filing rate }\end{array}$} \\
\hline & $\begin{array}{c}\text { Strategic } \\
\text { type }\end{array}$ & $\begin{array}{l}\text { Adverse } \\
\text { type }\end{array}$ & $\begin{array}{c}\text { Strategic } \\
\text { type }\end{array}$ & $\begin{array}{l}\text { Adverse } \\
\text { type }\end{array}$ & Total & $\begin{array}{c}\text { Strategic } \\
\text { type }\end{array}$ & $\begin{array}{c}\text { Adverse } \\
\text { type }\end{array}$ & Total \\
\hline $\begin{array}{l}\text { Percentage of no } \\
\text { work - } 5 \text { percentage } \\
\text { points (from mean } \\
23 \% \text { ) }\end{array}$ & $\begin{array}{l}0.3507 \\
(0.1075)\end{array}$ & $\begin{array}{l}0.0913 \\
(0.0524)\end{array}$ & $\begin{array}{c}0.0086 \\
(0.0034)\end{array}$ & $\begin{array}{l}3 e-5 \\
(7 e-5)\end{array}$ & $\begin{array}{l}0.0015 \\
(6.3 \mathrm{e}-4)\end{array}$ & 24.78 & 0.39 & 11.47 \\
\hline $\begin{array}{l}\text { Period of } \\
\text { unemployment }-0.5 \\
\text { week from mean } \\
2.39\end{array}$ & $\begin{array}{l}-1.7560 \\
(0.7640)\end{array}$ & $\begin{array}{l}-0.2147 \\
(0.0763)\end{array}$ & $\begin{array}{l}-0.0280 \\
(0.0091)\end{array}$ & $\begin{array}{l}-6.5 e-5 \\
(1.5 e-4)\end{array}$ & $\begin{array}{l}-0.0047 \\
(0.0017)\end{array}$ & -80.69 & -0.84 & -37.12 \\
\hline $\begin{array}{l}\text { Percentage with } \\
\text { health problems }-1 \\
\text { percentage point } \\
\text { (from mean } 4 \% \text { ) }\end{array}$ & $\begin{array}{l}-0.0148 \\
(0.0240)\end{array}$ & $\begin{array}{l}-0.0294 \\
(0.0153)\end{array}$ & $\begin{array}{l}-3.4 \mathrm{e}-4 \\
(1.3 \mathrm{e}-4)\end{array}$ & $\begin{array}{l}-9.4 e-6 \\
(2.2 \mathrm{e}-5)\end{array}$ & $\begin{array}{l}-6.5 e-5 \\
(4 e-5)\end{array}$ & -0.97 & -0.12 & -0.51 \\
\hline $\begin{array}{l}\text { Percentage of } \\
\text { divorce }-5 \\
\text { percentage points } \\
\text { (from mean } 13 \% \text { ) }\end{array}$ & $\begin{array}{l}-0.2218 \\
(0.0673)\end{array}$ & $\begin{array}{l}-0.1068 \\
(0.0381)\end{array}$ & $\begin{array}{l}-0.0048 \\
(0.0018)\end{array}$ & $\begin{array}{l}-3.3 e-5 \\
(7.7 e-5)\end{array}$ & $\begin{array}{l}-8.3 e-4 \\
(3.7 e-4)\end{array}$ & -13.83 & -0.43 & -6.51 \\
\hline
\end{tabular}


Table 9: Hausman Test

\begin{tabular}{|c|c|c|c|c|}
\hline & $\begin{array}{c}\text { Benchmark } \\
\text { model }\end{array}$ & $\begin{array}{l}\text { Without "shop } \\
\text { around" }\end{array}$ & $\begin{array}{l}\text { Without "risk } \\
\text { averse" and } \\
\text { "shop around" }\end{array}$ & $\begin{array}{l}\text { Without "log } \\
\text { income" and } \\
\text { "shop around" }\end{array}$ \\
\hline \multicolumn{5}{|l|}{ Type equation } \\
\hline Log income & $-0.6032 * * *$ & $-0.6029 * * *$ & $-0.5353 * * *$ & ---- \\
\hline Number of credit cards & $-0.1517 * * *$ & $-0.1516 * * *$ & $-0.2127 * *$ & -1.0439 \\
\hline Risk averse & 0.3554 & 0.3513 & ---- & 4.2633 \\
\hline Turn down for credit & 0.0218 & ---- & ---- & ---- \\
\hline constant & $6.2026^{* * *}$ & $6.2548 * * *$ & $5.8810 * * *$ & 5.1887 \\
\hline \multicolumn{5}{|c|}{ Key coefficients from the bankruptcy equation } \\
\hline Log financial benefit & $0.2282 * * *$ & $0.2188 * * *$ & $0.2414 * * *$ & $0.2228 * * *$ \\
\hline (strategic type) & $(0.0498)$ & $(0.0474)$ & $(0.0485)$ & $(0.0410)$ \\
\hline $\log$ financial benefit & 0.0155 & 0.0570 & 0.0017 & 0.0243 \\
\hline (adverse type) & $(0.0881)$ & $(0.0857)$ & $(0.0824)$ & $(0.0805)$ \\
\hline Correlation coefficient & $-0.5390 *$ & $-0.5343^{*}$ & $-0.5919 * *$ & $0.5827 * *$ \\
\hline (strategic type) & $(0.3011)$ & $(0.3036)$ & $(0.2945)$ & $(0.2369)$ \\
\hline $\begin{array}{l}\text { Correlation coefficient } \\
\text { (adverse type) }\end{array}$ & $\begin{array}{l}0.2505 \\
(0.4554)\end{array}$ & $\begin{array}{c}0.2400 \\
(0.4444)\end{array}$ & $\begin{array}{c}0.3541 \\
(0.4482)\end{array}$ & $\begin{array}{c}0.2875 \\
()\end{array}$ \\
\hline \multicolumn{5}{|l|}{$\underline{\text { Test Statistics }}$} \\
\hline Hausman test statistics & ---- & 0.01 & 4.38 & 6.36 \\
\hline p-value & ---- & 1 & 1 & 1 \\
\hline
\end{tabular}

The critical value of $\chi^{2}$ at significance level of $99 \%$ is 32 . 


\section{References}

Adams, W., L. Einav, and J. Levin (2009): "Liquidity constraints and imperfect information in subprime lending," American Economic Review, 99(1), 49-84

Arabmazar, A. and P. Schmidt (1982): "An investigation of the robustness of the Tobit estimator to nonnormality," Econometrica, 50, 1055-64.

Araujo, A. and M. Pascoa (2002): "Bankruptcy in a model of unsecured claims," Economic Theory, 20(3), 455-481.

Ausubel, L. M. (1991): "The failure of competition in the credit card market," American Economic Review," 81(1), 50-81.

Ausubel, L. M. (1997): “Credit card defaults, credit card profits, and bankruptcy," American Bankruptcy Law Journal, 71, 249-270.

Crow, E. L., and K. E. Shimizu (1988): Lognormal Distributions: Theory and Applications, Dekker, New York.

Domowitz, P. J. and R. L. Sartain (1999): “Determinants of the consumer bankruptcy decision,” Journal of Finance, 54(1), 403-420.

Dubey, P., J. Geanakoplos, and M. Shubik (2005): "Default and punishment in general equilibrium," Econometrica, 73(1), 1-37.

Elias, S., A. Renauer, and R. Leonard (1999): How to File for Chapter 7 Bankruptcy, Nolo Press

Fan, W. and M. J. White (2003): "Personal bankruptcy and the level of entrepreneurial activity," Journal of Law and Economics, 46(2), 543-568.

Fay, S., E. Hurst, and M. J. White (2002): “The household bankruptcy decision," American Economic Review, 92(3), 706-718.

Gan, L., M. Hurd, and D. McFadden (2005): "Individual subjective survival curves," in D. Wise ed., Analyses of Economics of Aging, The University of Chicago Press, 2005: 377-411.

Gan, L. and T. Sabarwal (2005): "A Simple Test of Adverse Events and Strategic Timing Theories of Consumer Bankruptcy," NBER Working Paper Series, No. 11763, November

Gan, Li, Feng Huang, and Adalbet Mayer (2010). "A simple test of private information in the insurance markets with heterogeneous insurance demand.” NBER Working Paper Series, No 16738.

Gan, L., and Roberto Mosquera (2008). “ An empirical study of the credit market with unobserved consumer types. "NBER Working Paper Series, No 13873.

Geanakoplos, J., and W. Zame (2007): “Collateralized Asset Markets," mimeo. 
General Accounting Office (1998): "Personal bankruptcy: the credit research center report on debtors' ability to pay," GAO/GGD-98-47.

General Accounting Office (1999): "Personal bankruptcy: a report on petitioner's ability to pay," GAO/GGD-99-103.

Gross, T, M.J.Notowidigdo, and J. Wang (2012): "Liquidity Constraints and Consumer Bankruptcy: Evidence From Tax Rebates," NBER Working Paper Series, No. 17807

Han, S. and G. Li (2009): "Household borrowing after personal bankruptcy," working paper, Finance and Economics Discussion Series, 2009-17

Henry, Marc, Yuichi Kitamura, and Bernard Salanié (2010). "Identifying finite mixtures in econometric models.” Cowels Foundation Discussion Paper No. 1767. September 2010.

Hoelle, M. (2009): “A Simple Model of Bankruptcy in General Equilibrium," working paper, University of Pennsylvania

Kennickell, A., M. Starr-McCluer, and B. J. Surette (2000). "Recent change in U.S. family finances: results from the 1998 Survey of Consuemr Finances." Federal Reserve Bulletin, Division of Research and Statistics, Federal Reserve Board

Livshits, I, J. Macgee, and M. Tertilt (2007): “Consumer bankruptcy: a fresh start," American Economic Review, 97(1), 402-418

Livshits, I, J. Macgee, and M. Tertilt (2008): “Accounting for the rise in consumer bankruptcies," NBER Working Paper Series, No. 13363

Luckett, C. A. (2002): "Personal Bankrtupcies," The Impact of Public Policy on Consumer Credit, 69-108

Modica, M., A. Rustichini, and J. M. Tallon (1999): "Unawareness and bankruptcy: a general equilibrium model," Economic Theory, 12(2), 259-292.

Musto, D. K. (2004): "What happens when information leaves a market? Evidence from post bankruptcy consumers," Journal of Business, 77(4), 1-24

Powell, J. (1984): "Least absolute deviations estimation for the censored regression model," Journal of Econometrics, 25: 303-325.

Elias, S., A. Renauer, and R. Leonard (1999): How to file for chapter 7 bankruptcy, Nolo Press, 8th edition

Sabarwal, T. (2003): "Competitive equilibria with incomplete markets and endogenous bankruptcy," Contributions to Theoretical Economics, 3(1), Art. 1.

Stanley, D. T., and M. Girth (1971): Bankruptcy: problem, process, reform. Brookings Institution, Washington DC 
Sullivan, T. A., E. Warren, and J. L. Westbrook (1989): As we forgive our debtors. Oxford University Press

Sullivan, T. A., E. Warren, and J. L. Westbrook (1994): "Consumer debtors ten years later: a financial comparison of consumer bankrupts, 1981-1991," American Bankruptcy Law Journal, 68, 121 154.

Sullivan, T. A., E. Warren, and J. L. Westbrook (2000): The Fragile Middle Class. Yale University Press

Warren, C. (1935): Bankruptcy in United States history. Harvard University Press

White, M. J. (1987): "Personal bankruptcy under the 1978 bankruptcy code: an economic analysis," Indiana Law Journal, 63(1), 1-53.

White, M. J. (1998): “Why don't more households file for bankruptcy?" Journal of Law, Economics, and Organization, 14(2), 205-231.

Zame, W. (1993): "Efficiency and the role of default when security markets are incomplete," American Economic Review, 83(5), 1142-1164. 


\section{Appendix A}

A1. Simple Two-Period Model: Consider a standard, two-period decision-making framework. In the first period, there is one decision node. In the second period, one of three states of the world prevails; a good state, indexed $g$, a bad state, $b$, and a terrible state, $t$, thought of as an adverse events state. Each state corresponds to a decision node, and the probability of each state is $\pi_{g}, \pi_{b}$, and $\pi_{t}$, respectively, with $\pi_{g}+\pi_{b}$ $+\pi_{t}=1$.

As usual, a consumer has to decide how much to consume at each node; his consumption is indexed $c_{0}, c_{g}$, $c_{b}$, and $c_{t}$. Moreover, lending markets are available to him at a one-period, risk-adjusted, market interest rate $r$. As usual, a single consumer takes interest rates as given. His endowment in consumption units at each node is denoted $w_{0}, w_{g}, w_{b}$, and $w_{t}$. (For convenience, suppose $w_{0}=0$, and $0<w_{t}<w_{b}<w_{g}$.) Moreover, he has to decide how much debt to take, subject to some exogenously specified debt limit; indexed $\bar{d}>0$. His twice continuously differentiable von Neumann-Morgenstern utility is denoted $u(c)$ with $u^{\prime}>0, u^{\prime \prime}<0, \lim _{c \rightarrow 0} u^{\prime}(c)=\infty, \lim _{c \rightarrow \infty} u(c)=\infty$. His expected utility is $U=u\left(c_{0}\right)+\delta\left[\pi_{g} u\left(c_{g}\right)+\pi_{b} u\left(c_{b}\right)+\pi_{t} u\left(c_{t}\right)\right]$.

A2. Adverse Events: An adverse events consumer takes decisions sequentially. In period 1, he plans for states $g, b$, and he plans to remain solvent in these states, but he does not plan for state $t$, the adverse events state. In period 2, if $g$ or $b$ occurs, he consumes as planned, but if $t$ occurs, he considers the option to file for bankruptcy. There are some costs of filing for bankruptcy; usually some loss of assets, court fees, lawyer fees, limited future participation in debt markets, and so on. Benefits of filing include, among others, discharge of debt, fresh start, and accompanying wealth insurance. Adapting a simple form of a Chapter 7 filing, ${ }^{23}$ it is assumed that a filer gives up all his assets except any exemptions from forfeiture provided by law, and his debt is discharged. ${ }^{24}$ Exemptions specified under law are summarized by $e$. Consequently, an adverse events consumer solves the following problem.

\footnotetext{
${ }^{23}$ Historically, Chapter 7 bankruptcies account for about 70 percent of all bankruptcies.

${ }^{24}$ The other main personal bankruptcy category, Chapter 13 bankruptcy, accounting for about 29 percent of all cases, can be viewed in this formulation as follows. In this type of filing, a repayment plan proposed by the debtor is confirmed by the Court, and a discharge of remaining debt is provided on successful completion of the plan. In this case, net assets saved and debts discharged depend on the repayment plan, and can be mapped to this model after an appropriate discounting for period of plan. Exemptions provided under law are the same in both cases.
} 
Stage $I: \max _{d, c_{0}, c_{g}, c_{b}} u\left(c_{0}\right)+\delta\left[\pi_{g} u\left(c_{g}\right)+\pi_{b} u\left(c_{b}\right)\right]$

subject to $c_{0}=d$

$c_{g}=w_{g}-(1+r) d$

$c_{b}=w_{b}-(1+r) d$

$d \leq \bar{d}$

Stage II : If $t$, then set :

$c_{t}=\max \left(w_{t}-(1+r) d, \min \left(w_{t}, e\right)\right)$

In Stage I, a consumer decides optimal debt and consumption $\left(d, c_{0}, c_{g}, c_{b}\right)$, and by assumption, he does not file in $g, b$. Given $d>0$, and $w_{t}<e$, in Stage II, if $t$ occurs, optimal choice is to file and consume $c_{t}=$ $w_{t}$.

\section{Solution to optimization problem for an adverse events consumer}

Notice that the first-order condition for the consumer's stage I problem is:

$M U^{A E}(d)=u^{\prime}(d)-\delta(1+r) \pi_{g} u^{\prime}\left(w_{g}-(1+r) d\right)-\delta(1+r) \pi_{b} u^{\prime}\left(w_{b}-(1+r) d\right)=0$. Moreover, as $\lim _{d \downarrow 0} u^{\prime}(d)=\infty$, for $d$ small enough, $M U^{A E}(d)>0$, and for $d$ sufficiently large, $w_{g}-(1+r) d$, and $w_{b}$ $(1+r) d$ are sufficiently small, and hence, $M U^{A E}(d)<0$. Therefore, there is unique $d^{*} \equiv d^{* A E}>0$ such that $M U^{A E}\left(d^{* A E}\right)=0$. Furthermore, it is easy to check that $\partial M U^{A E}(d) / \partial d<0$, and consequently, if $d \leq d^{* A E}$, then $M U^{A E}(d) \geq M U^{A E}\left(d^{* A E}\right)$, and if $d>d^{* A E}$, then $M U^{A E}(d)<M U^{A E}\left(d^{*} A E\right)$. Comparisons with strategic filing consumers are provided below.

A3. Strategic Filing: A strategic filing consumer is a standard fully rational consumer who includes the bankruptcy option in her maximization problem. Assumptions regarding decision nodes, endowments, utility functions, and expected utility are the same as in the previous case. Moreover, it is assumed that the bankruptcy process is the same as in the previous case. Of course, the difference is in the optimization problem. In each state in the second period, a strategic filing consumer has an option to file for bankruptcy, and solves the following problem.

$$
\begin{aligned}
& \max _{d, c 0, c g, c b, \text { File }, \text { Not }} u\left(c_{0}\right)+\delta\left[\pi_{g} u\left(c_{g}\right)+\pi_{b} u\left(c_{b}\right)+\pi_{t} u\left(c_{t}\right)\right] \\
& \text { subject to } c_{0}=d \\
& c_{g}=\max \left(w_{g}-(1+r) d, \min \left(w_{g}, e\right)\right) \\
& c_{b}=\max \left(w_{b}-(1+r) d, \min \left(w_{b}, e\right)\right) \\
& c_{t}=\max \left(w_{t}-(1+r) d, \min \left(w_{t}, e\right)\right) \\
& d \leq \bar{d}
\end{aligned}
$$


The maximum operator for decision nodes in the second period corresponds to the bankruptcy decision. For example, if a consumer decides not to file in $g$, her constraint is $w_{g}-(1+r) d$, and if she decides to file, her constraint is $\min (w, e)$, where, as before, $e$ captures exemptions permitted in bankruptcy.

\section{Solution to optimization problem for a strategic filing consumer}

For the state $g$, the optimal decision of a strategic filing consumer can be characterized as follows. Notice that utility of filing in $g$, when debt is $d$, is $U($ file, $d)=u(d)+\delta\left[\pi_{g} u(e)+\pi_{b} u\left(w_{b}\right)+\pi_{t} u\left(w_{t}\right)\right]$, and utility of not filing is $U($ not, $d)=u(d)+\delta\left[\pi_{g} u\left(c_{g}\right)+\pi_{b} u\left(w_{b}\right)+\pi_{t} u\left(w_{t}\right)\right]$.

Consider the action of not filing. Then marginal utility is: $M U^{S T}(n o t, d)=u^{\prime}(d)-\delta(1+r) \pi_{g} u^{\prime}\left(c_{g}\right)$.

Notice that marginal utility is decreasing in debt, because $\partial M U^{S T}($ not,$d) / \partial d=u^{\prime \prime}(d)+\delta(1+r)^{2} \pi_{g} u^{\prime \prime}\left(c_{g}\right)<0$. Moreover, $\lim _{d \downarrow 0} u^{\prime}(d)=\infty$, implies that for $d$ small enough, $M U^{S T}($ not, $d)>0$, and for $d$ sufficiently large, $w_{g}-(1+r) d$ is sufficiently small, and hence, $M U^{S T}($ not, $d)<0$. Therefore, there is a unique $d^{*}>0$ such that $M U^{S T}\left(\right.$ not, $\left.d^{*}\right)=0$. Furthermore, $\partial M U^{S T}($ not, $d) / \partial d<0$ implies that if $d<d^{*}$, then $M U^{S T}(\operatorname{not}, d) \geq M U^{S T}\left(\right.$ not, $\left.d^{*}\right)$, and if $d>d^{*}$, then $M U^{S T}$ (not, $\left.d\right)<M U^{S T}$ (not, $d^{*}$ ). Consequently, if a consumer considers not filing, then maximum utility possible when debt limit is $\bar{d}$ is as follows: if $\bar{d} \leq d^{*}$, then maximum utility is $U($ not, $\bar{d})=u(\bar{d})+\delta\left[\pi_{g} u\left(w_{g}-(1+r) \bar{d}\right)+\pi_{b} u\left(w_{b}\right)+\pi_{t} u\left(w_{t}\right)\right]$, and if $\bar{d}>d^{*}$, then maximum utility is: $U\left(\operatorname{not}, d^{*}\right)=u\left(d^{*}\right)+\delta\left[\pi_{g} u\left(w_{g}-(1+r) d^{*}\right)+\pi_{b} u\left(w_{b}\right)+\pi_{t} u\left(w_{t}\right)\right]$.

Consider the action of filing. Then marginal utility is $M U^{S T}($ file, $d)=u^{\prime}(d)>0$, and consequently, the optimal debt choice is to set $d=\bar{d}$. Therefore, if a consumer considers filing, the maximum utility when debt limit is $\bar{d}$ is: $U($ file,, $\bar{d})=u(\bar{d})+\delta\left[\pi_{g} u(e)+\pi_{b} u\left(w_{b}\right)+\pi_{t} u\left(w_{t}\right)\right]$.

In order to characterize the optimal decision, it is useful to define the level of debt at which the consumer is financially indifferent between filling or not. That is, let $\hat{d}$ solve $w_{g}-(1+r) \hat{d}=e$. In other words, let $\hat{d}=\left(w_{g}-e\right) /(1+r)$. Suppose $\bar{d} \leq \hat{d}$. That is, debt limit is small relative to $\hat{d}$. (In other words, $e=w_{g}-(1+r) \hat{d} \leq w_{g}-(1+r) \bar{d}$. That is, exemptions are small relative to net wealth after maximum possible debt payoff.) Then the consumer's optimal decision is not to file in $g$. This can be seen by separately considering two cases: $\bar{d} \leq d^{*}$, and $\bar{d}>d^{*}$. If $\bar{d} \leq d^{*}$, then maximum utility from not filing is: $U(\operatorname{not}, \bar{d})=u(\bar{d})+\delta\left[\pi_{g} u\left(w_{g}-(1+r) \bar{d}\right)+\pi_{b} u\left(w_{b}\right)+\pi_{t} u\left(w_{t}\right)\right]$, and maximum utility from filing is $U($ file,, $\bar{d})=u(\bar{d})+\delta\left[\pi_{g} u(e)+\pi_{b} u\left(w_{b}\right)+\pi_{t} u\left(w_{t}\right)\right]$. Moreover, $\bar{d} \leq \hat{d}$ implies that $e=w_{g}-(1+r) \hat{d} \leq w_{g}-(1+r) \bar{d}$, and consequently, $U(\operatorname{not}, \bar{d}) \geq U($ file, $\bar{d})$. If $\bar{d}>d^{*}$, then maximum utility from not filing is:

$U\left(\right.$ not, $\left.d^{*}\right)=u\left(d^{*}\right)+\delta\left[\pi_{g} u\left(w_{g}-(1+r) d^{*}\right)+\pi_{b} u\left(w_{b}\right)+\pi_{t} u\left(w_{t}\right)\right]$, 
and maximum utility from filing is $U($ file, $\bar{d})=u(\bar{d})+\delta\left[\pi_{g} u(e)+\pi_{b} u\left(w_{b}\right)+\pi_{t} u\left(w_{t}\right)\right]$. Moreover, $\bar{d} \leq \hat{d}$, and the optimality of $d^{*}$ imply that

$u\left(d^{*}\right)+\delta \pi_{g} u\left(w_{g}-(1+r) d^{*}\right)>u(\bar{d})+\delta \pi_{g} u\left(w_{g}-(1+r) \bar{d}\right) \geq u(\bar{d})+\delta \pi_{g} u(e)$, and consequently, $U\left(\operatorname{not}, d^{*}\right) \geq U(\operatorname{not}, \bar{d}) \geq U($ file, $\bar{d})$.

Consider now the case $\bar{d}>\hat{d}$. That is, debt limit is large relative to $\hat{d}$. (In other words, $e=w_{g}-(1+r) \hat{d}>w_{g}-(1+r) \bar{d}$. That is, exemptions are large relative to net wealth after maximum possible debt payoff.) Then the filing decision is a little more nuanced, and it depends on the tradeoff between exemptions and net wealth after paying off endogenously determined debt use. This can be seen by separately considering the following cases: when $\hat{d} \leq d^{*}$ (that is, exemptions are large relative to net wealth after paying off optimal debt in the case of not filing) and when $\hat{d}>d^{*}$ (that is, exemptions are small relative to net wealth after paying off optimal debt in the case of not filing).

Suppose $\hat{d} \leq d^{*}$. (In other words, exemptions are large relative to wealth after paying off $d^{*}$.) Then the optimal decision is to file, and it can be seen by considering the following two cases. If $\bar{d} \leq d^{*}$, then maximum utility from not filing is:

$U($ not, $\bar{d})=u(\bar{d})+\delta\left[\pi_{g} u\left(w_{g}-(1+r) \bar{d}\right)+\pi_{b} u\left(w_{b}\right)+\pi_{t} u\left(w_{t}\right)\right]$, and maximum utility from filing is $U($ file, $\bar{d})=u(\bar{d})+\delta\left[\pi_{g} u(e)+\pi_{b} u\left(w_{b}\right)+\pi_{t} u\left(w_{t}\right)\right]$. Moreover, $\bar{d}>\hat{d}$ implies that $e=w_{g}-(1+r) \hat{d}>w_{g}-(1+r) \bar{d}$, and consequently, $U($ file, $\bar{d})>U($ not, $\bar{d})$. If $\bar{d}>d^{*}$, then maximum utility from not filing is $U\left(\right.$ not, $\left.d^{*}\right)=u\left(d^{*}\right)+\delta\left[\pi_{g} u\left(w_{g}-(1+r) d^{*}\right)+\pi_{b} u\left(w_{b}\right)+\pi_{t} u\left(w_{t}\right)\right]$, and maximum utility from filing is $U($ file, $\bar{d})=u(\bar{d})+\delta\left[\pi_{g} u(e)+\pi_{b} u\left(w_{b}\right)+\pi_{t} u\left(w_{t}\right)\right]$. Moreover, $\hat{d} \leq d^{*}$ implies that $e=w_{g}-(1+r) \hat{d}>w_{g}-(1+r) \bar{d}$, and consequently, $U($ file, $\bar{d})>U($ not, $\bar{d})$.

Suppose $\hat{d}>d^{*}$. (Exemptions are small relative to $d^{*}$.) Then there is a unique $\bar{d}^{*}, \hat{d}<\bar{d}^{*}$, such that if $\hat{d}<\bar{d}<\bar{d}^{*}$, then optimal decision is to not file, and if $\bar{d}^{*}<\bar{d}$, then optimal decision is to file. This case highlights an interesting dynamic. In this case, relatively high debt limits additionally affect a consumer's decision to file. That is, even when exemptions are relatively small as compared to a consumer's desired debt (when not filing), she may decide to file, if her debt limit is sufficiently high to make the intertemporal consumption tradeoff valuable. This sufficiently high threshold is characterized by $\bar{d}^{*}$. Recall from a previous case that if $\hat{d}=\bar{d}$ and $\hat{d}>d^{*}$, then $U\left(\right.$ not, $\left.d^{*}\right)>U($ file, $\bar{d})$. In other words, if exemptions are the same as net wealth after maximum debt payoff, but consumer's optimal use 
of debt is smaller than maximum debt allowed, then it is beneficial for the consumer to not file, essentially because the additional consumption in period 1 from additional debt does not compensate for the decrease in consumption in state $g$ that results from filing. Therefore, for $\bar{d}$ slightly larger than $\hat{d}$, $U\left(\right.$ not,$\left.d^{*}\right)>U($ file, $\bar{d})$. However, in the region $\left[d^{*}, \infty\right), \partial U($ not,$d) / \partial d^{*}=0$, and, $\partial U($ file, $\bar{d}) / \partial \bar{d}=u^{\prime}(\bar{d})>0$. In other words, maximum utility from filing is strictly increasing in $\bar{d}$, while maximum utility from not filing is constant. Moreover, $u$ is unbounded above. Consequently, there is a unique $\bar{d}^{*}, \hat{d}<\bar{d}^{*}$, such that for each $\bar{d}$, if $\hat{d}<\bar{d}<\bar{d}^{*}$, then optimal choice is to not file, and if $\bar{d}^{*}<\bar{d}$, then optimal choice is to file.

\section{A.4 Comparisons between the Hypotheses and Empirical Predictions}

One distinction between strategic filing and adverse events hypothesis is that for strategic filing consumers, the bankruptcy decision and the debt decision (and consequently, financial benefit) are jointly determined, whereas for adverse events consumers, the debt decision (and consequently, financial benefit) is exogenous to the filing decision. This follows immediately from the construction of the models.

For the clearest distinctions between the two hypotheses in terms of financial benefits and probabilities of filing, suppose $0<w_{t}<w_{b} \leq e<w_{g}$. That is, exemptions are sufficiently high to have non-negative financial benefit from filing in bad and terrible states, but not necessarily in a good state. ${ }^{25}$

In this case, strategic filing consumers file for bankruptcy in states $t$ and $b$, and perhaps in $g$ as well, whereas adverse events consumers file only in state $t$. Therefore, a second distinction is that adverse events consumers may file less frequently (or equivalently, with lower probability) than strategic filing consumers.

Another intuitive comparative statics result that can be seen here formally is that debt use by adverse events consumers is sometimes less, and never more than that for strategic filing consumers. Of course, when debt limits are sufficiently low, both types might decide to use maximum possible debt, and in this case, debt levels are the same. But notice that the optimal debt level for adverse events consumers can be lower than that for strategic filing consumers, because for every $d$,

\footnotetext{
${ }^{25}$ Appendix A presents details on utility maximizing solutions in this case.
} 


$$
\begin{array}{rrrr}
M U^{A E}(d) & =u^{\prime}(d)-\delta(1+r) \pi_{g} u^{\prime}\left(w_{g}-(1+r) d\right)-\delta(1+r) \pi_{b} u^{\prime}\left(w_{b}-(1+r) d\right) \\
<u^{\prime}(d)-\delta(1+r) \pi_{g} u^{\prime}\left(w_{g}-(1+r) d\right) & {\left[=M U^{S T}(\text { not }, d)\right]} \\
<u^{\prime}(d) & & {\left[=M U^{S T}(\text { file }, d)\right]}
\end{array}
$$

Here, $M U^{S T}$ (not, $d$ ) is the marginal utility to the strategic consumer from not filing in state $g$ when debt is $d$, and $M U^{S T}$ (file, $d$ ) is the marginal utility to the strategic consumer from filing in state $g$ when debt is $d$. Therefore, if not filing in $g$ is optimal for the strategic consumer, then $M U^{A E}\left(d^{* S T}\right)<M U^{S T}\left(\operatorname{not}, d^{* S T}\right)=0=M U^{A E}\left(d^{*} A E\right)$, whence $d^{* A E}<d^{* S T}$. (Here, $d^{* A E}$ is the optimal debt level for the adverse events consumer, $d^{* S T}$ for the strategic consumer, and we used the easy-tocheck fact that $\partial M U^{A E}(d) / \partial d<0$.) Similarly, if filing in $g$ is optimal for the strategic consumer, then $M U^{A E}\left(d^{* S T}\right)<M U^{S T}\left(\right.$ file, $\left.d^{* S T}\right)=0=M U^{A E}\left(d^{* A E}\right)$, and again, $d^{* A E}<d^{* S T}$. Consequently, unsecured debt (and therefore, financial benefit from filing) is larger for strategic consumers than for adverse events consumers.

In summary, the empirical predictions from the theoretical analysis include: (a) financial benefit is endogenous to the bankruptcy decision in the strategic filing hypothesis and exogenous in the adverse events hypothesis; and (b) financial benefit and probability of filing for bankruptcy are higher in strategic filing hypothesis than in adverse events hypothesis.

\section{Appendix B}

This appendix presents the joint density of $\log$ of $(\mathrm{bank}, \ln (\mathrm{fb}+1))$ if both adverse event type and the strategic type people are potentially present but unobserved.

The join density (file, $\ln (\mathrm{fb}+1))$ is given by:

$$
\begin{aligned}
& f(\text { file }, \ln (f b+1) \mid X, A E, W)= \\
& f((\text { file }, \ln (f b+1) \mid T=1, X, A E, W)) \operatorname{Pr}(T=1 \mid X, A E, W)+ \\
& f((\text { file, } \ln (f b+1) \mid T=2, X, A E, W)) \operatorname{Pr}(T=2 \mid X, A E, W)
\end{aligned}
$$

We assume that the set of $W$ is such that $\operatorname{Pr}(T=1 \mid X, A E, W)=\operatorname{Pr}(T=1 \mid W)=\Phi(W \alpha)$, and

$f(($ file $, \ln (f b+1) \mid T=1, X, A E, W))=f(($ file $, \ln (f b+1) \mid T=1, X, A E))$. In other words, the set of $\mathrm{W}$ only affects of probability of being in one of the two types. It does not affect conditional joint density of (file, $\ln (\mathrm{fb}+1) \mid \mathrm{T})$.

The join density of (file, $\ln (\mathrm{fb}+1))$ consists four observed cases, $($ file $=1, \ln (\mathrm{fb}+1)=0),($ file $=0$, $\ln (\mathrm{fb}+1)=0),($ file $=1, \ln (f b+1))$, and $($ file $=0, \ln (\mathrm{fb}+1))$. 


$$
\begin{aligned}
& \operatorname{Pr}(\text { file }=1, \ln (f b+1)=0) \\
& =\operatorname{Pr}(\text { file }=1, \ln (f b+1)=0 \mid T=1) \operatorname{Pr}(T=1)+\operatorname{Pr}(\text { file }=1, \ln (f b+1)=0 \mid T=2) \operatorname{Pr}(T=2) \\
& =\Phi(W \alpha) * \int_{-\infty}^{-X \delta_{1}-\mu_{1} A E} \Phi\left(\frac{X \beta_{1}+\theta_{1} v_{1}}{\sqrt{1-\theta_{1}^{2} \sigma_{v 1}^{2}}}\right) \frac{1}{\sigma_{v 1}} \phi\left(\frac{v_{1}}{\sigma_{v 1}}\right) d v_{1}+(1-\Phi(W \alpha)) * \Phi\left(X \beta_{2}\right) * \Phi\left(-\frac{X \delta_{2}+\mu_{2} A E}{\sigma_{v 2}}\right)
\end{aligned}
$$

Similarly,

$$
\begin{aligned}
& \operatorname{Pr}(\text { file }=0, \ln (f b+1)=0) \\
& =\operatorname{Pr}(\text { file }=0, \ln (f b+1)=0 \mid T=1) \operatorname{Pr}(T=1)+\operatorname{Pr}(\text { file }=0, \ln (f b+1)=0 \mid T=2) \operatorname{Pr}(T=2) \\
& =\Phi(W \alpha) \int_{-\infty}^{-X \delta_{1}-\mu_{1} A E} \Phi\left(-\frac{X \beta_{1}+\gamma_{1} \ln (f b+1)+\theta_{1} v_{1}}{\sqrt{1-\theta_{1}^{2} \sigma_{v 1}^{2}}}\right) \frac{1}{\sigma_{v_{1}}} \phi\left(\frac{v_{1}}{\sigma_{v 1}}\right) d v_{1} \\
& \quad+(1-\Phi(W \alpha)) \cdot\left[1-\Phi\left(X \beta_{2}\right)\right] \cdot \Phi\left(-\frac{X \delta_{2}+\mu_{2} A E}{\sigma_{v 2}}\right)
\end{aligned}
$$

Additionally,

$\operatorname{Pr}($ file $=1, \ln (f b+1))$

$=\operatorname{Pr}($ file $=1, \ln (f b+1) \mid T=1) \operatorname{Pr}(T=1)+\operatorname{Pr}($ file $=1, \ln (f b+1) \mid T=2) \operatorname{Pr}(T=2)$

$=\Phi(W \alpha) \cdot \Phi\left(\frac{X \beta_{1}+\gamma_{1} \ln (f b+1)+\theta\left(\ln (f b+1)-X \delta_{1}-\mu_{1} A E\right)}{\sqrt{1-\theta_{1}^{2} \sigma_{v 1}^{2}}}\right) \frac{1}{\sigma_{v 1}} \phi\left(\frac{\ln (f b+1)-X \delta_{1}-\mu_{1} A E}{\sigma_{v 1}}\right)+$

$(1-\Phi(W \alpha)) \cdot \Phi\left(X \beta_{2}+\gamma_{2} \ln (f b+1)\right) \cdot \frac{1}{\sigma_{v 2}} \phi\left(\frac{\ln (f b+1)-X \delta_{2}-\mu_{2} A E}{\sigma_{v 2}}\right)$

And finally,

$\operatorname{Pr}($ file $=0, \ln (f b+1))$

$=\operatorname{Pr}($ file $=0, \ln (f b+1) \mid T=1) \operatorname{Pr}(T=1)+\operatorname{Pr}($ file $=0, \ln (f b+1) \mid T=2) \operatorname{Pr}(T=2)$

$=\Phi(W \alpha)\left[1-\Phi\left(\frac{X \beta_{1}+\gamma_{1} \ln (f b+1)+\theta\left(\ln (f b+1)-X \delta_{1}-\mu_{1} A E\right)}{\sqrt{1-\theta_{1}^{2} \sigma_{v 1}^{2}}}\right)\right] \frac{1}{\sigma_{v 1}} \phi\left(\frac{\ln (f b+1)-X \delta_{1}-\mu_{1} A E}{\sigma_{v 1}}\right)+$

$(1-\Phi(W \alpha)) \cdot\left[1-\Phi\left(X \beta_{2}+\gamma_{2} \ln (f b+1)\right)\right] \cdot \frac{1}{\sigma_{v 2}} \phi\left(\frac{\ln (f b+1)-X \delta_{2}-\mu_{2} A E}{\sigma_{v 2}}\right)$ 